\title{
Can We Trace and Estimate the Technical Progress in Shipping Industry by Using the Cobb-Douglas Production Function?
}

\author{
Alexandros M. Goulielmos ${ }^{1,2}$, Constantinos Giziakis ${ }^{3}$, Evangelos Sambracos ${ }^{4}$ \\ ${ }^{1}$ Faculty of Maritime and Industrial Studies, Department of Maritime Studies, University of Piraeus, Piraeus, Greece \\ ${ }^{2}$ Professor Emeritus of Shipping, Transport and Logistics Department, Business College of Athens, Athens, Greece \\ ${ }^{3}$ Former Professor of Maritime Economics and Policy at University of Piraeus Department of Maritime Studies, Piraeus, Greece \\ ${ }^{4}$ Retired from the Department of Economics, University of Piraeus, Piraeus, Greece \\ Email: ag@unipi.gr,am.goulielmos@hotmail.com, agoulielmos@bca.edu.gr,kgiziakis@unipi.gr, sambra@unipi.gr
}

How to cite this paper: Goulielmos, A. M., Giziakis, C., \& Sambracos, E. (2021). Can We Trace and Estimate the Technical Progress in Shipping Industry by Using the CobbDouglas Production Function? Modern Economy, 12, 1563-1592.

https://doi.org/10.4236/me.2021.1210079

Received: August 7, 2021

Accepted: October 26, 2021

Published: October 29, 2021

Copyright $\odot 2021$ by author(s) and Scientific Research Publishing Inc. This work is licensed under the Creative Commons Attribution International License (CC BY 4.0).

http://creativecommons.org/licenses/by/4.0/

\begin{abstract}
This paper had an ambition: to estimate the impact of Technical Progress embodied in vessels. Given that technical progress is estimated in physical terms, we went a step further to estimate it also in $\$$ terms, and this found equal to $8.2 \%$ p.a. The monetary technical progress is more meaningful to managers. First, we found the existence of economies of scale in tankers using the generalized Cobb-Douglas production function: $P_{t}=A_{t} C_{t}^{\beta} L_{t}^{\alpha}$, where $\alpha+$ $\beta$ set $>1$; the parameter $\alpha$ set equal to 0.15 and the parameter $\beta$ set equal to 0.94 , based on actual data. The paper presented a historical account of the events since 1945, which we held responsible for the diffusion of a subsequent technical progress. Technical progress in ships-most of it is called to solve technical problems. Ships were regressing round 10,000 dwt, at relatively low speeds, after the $2^{\text {nd }}$ World War, and they consumed a lot of fuel oil, but who cared (?) as oil was very cheap. Sea trade did not stay at low levels, but increased by leaps and bounds after the $2^{\text {nd }}$ World War. Ships soon multiplied their size by 6 times initially and then by more than 10 times. Tank(ers), suitable to reap economies of scale, increased by 10 times, and eventually held the titles: VLCC \& ULCC, passing over various adventures! During 19451973, all maritime variables were increasing, and even Onassis, an empirical shipowner and uneducated, understood well the arithmetic of scale economies, even before the $2^{\text {nd }}$ World War by building the $1^{\text {st }}$ super-tanker (1938)! Then, suddenly, and unexpectedly, Suez Canal closed (1956). Ships had to travel a lot more sea miles... as a result they became even bigger than proper for the future trade. Ships fell into the trap, however, believing that Suez Canal will open after a very long time-even Onassis believed this. Shipowners
\end{abstract}


run to build giant ships! And all were going well till end-1973, for 16 years. Onassis and other tanker shipowners became rich during this time. OPEC, however, decided to change history (in end-1973) and to put an end in the story that oil is very cheap. The "trap" worked, as ships had become already bigger, faster, and covered longer distances, before fuel oil price increased about 10 times reaching $\$ 200$ per ton from $\$ 20$ ! Ships broadcast an SOS to... technical progress "telling" please: find a "cheaper oil and newer engines consuming less"! Technical progress responded... Today, a lot of discussion is going-on not for a cheaper fuel-oil, or a better main engine, but for a fuel oil... which will respect environment, e.g., LNG or hydrogen or else? Will shipping technical progress take revenge, in 2022 and thereafter on OPEC, on behalf of shipowners, by making ships free from oil? A new history for shipping is going to be written again...but this time will be a revolution, after Pandemic is over after 2022.

\section{Keywords}

Cobb-Douglas Production Function, Estimation of Increasing Scale Economies in Shipping, Estimation of Technical Progress in Ship Production, and in $\$$ Terms, History of Events and Technical Progress in Shipping, $1945-2021$

\section{Introduction}

One of the most researched subjects in economics, we believe, is "technical progress"- TP, which played a basic role in economic growth models, in 1928, and especially between 1939 and 1967, starting with Ramsey's article on “optimal growth" in Economic Journal (Ramsey, 1928).

Is, however, technical progress - TP a product of...business magic? Because, how one company, using technical progress, can achieve a higher production with unchanged quantities of Capital and Labor? Should we accept the idea that TP is something falling from Heaven, like a manna? Or is something man-made? This type of technical progress is called disembodied.

Certain great economists, namely Hicks, Harrod and Solow embarked in determining the so-called neutral TP (Table 1). Neutral technical progress is defined as the one, which in its initial effects, leaves unchanged the ratio of marginal product of Capital over that of Labor. Solow found out that about $80 \%$ of the growth in USA output per worker was due to technical progress. Solow

Table 1. The neutral technical progress, 1948-1963.

\begin{tabular}{ccc}
\hline Author-Year & Assumption of constancy of & Remarks \\
\hline Hicks, 1963 & Capital/Labor ratio & Neutral technical progress \\
Harrod, 1948 & Capital/Output ratio & Neutral technical progress \\
Solow, 1959 & Labor/Output ratio & Neutral technical progress \\
\hline
\end{tabular}

Source: author. 
eventually allowed in his models - as we did-the capital embodied in machinery to have different ages (vintages). Important was that the more recent vintages had more technical progress. Eventually economists - as we did-found that capital is more important for growth.

Hicks (1963) compared points in the growth process, during which the ratio of the marginal product of Capital and Labor is constant. Hick's model assumes, in 2 cases, labor and capital savings. Solow's neutral technical progress, allows capital to increase. Harrod (1948) defined neutral advances those that leave the distribution of the total national product between labor and capital unchanged (at a constant rate of interest).

In shipping, shipbuilding has to achieve less labor quantity on board and inevitably more capital quantity. If both can be reduced, it would be perfect, but by reducing the quantity of capital, we do not want to part from scale economies! In shipping, the $\mathrm{Ct} / \mathrm{Lt}$ and Lt/Qt ratios are apparently constant... because the size of the vessel (productive capacity-quantity of capital) is fixed and the number of crew is theoretically also fixed, after ship's construction. Production, however, is not fixed, depending mainly: on demand, on distance involved, and on vessel's speed!

We have to say from the start. Speed in shipping, is an important factor, because it transfers ship's production from origin to destination, adding utility to cargo, or in other words, speed performs the delivery stage of the cargo transported by sea. In addition, speed is a coefficient demonstrating also prevailing technology! The unfortunate fact is that higher speed needs more fuel, and fuel has become an expensive commodity, since end-1973, with the exception of the Pandemic period, 2019-2022!

\section{Literature Review}

Cobb and Douglas (1928) were not preoccupied so much with "technical progress", we believe. Their main concern was, using a production function $P=b C^{1-\alpha} L^{\alpha} \quad$ (1), to prove the existence of constant returns to scale, where $b$ indicates technology, $C$, the Capital quantity, $L$, the labor quantity and $P$, the production.

They wanted primarily to prove, using data, that $\alpha+(1-\alpha)=1$ (2) (Douglas, 1934). The implication of (2) is great for distribution theory. If (2) holds, then each factor of production gets the value of its marginal product (Henderson \& Quandt, 1958: p. 64)1. Accordingly, the total value of production is "given" to these two factors, and there is no monopoly profit! The above is also known as “Euler's theorem³ (Chiang \& Wainwright, 2005: p. 387).

\footnotetext{
${ }^{1}$ Proof: let $Q_{t}=A L^{\alpha} C^{1-\alpha} \quad$ (3); and $Q_{t}=L\left(\alpha A L^{\alpha-1} C^{1-\alpha}\right)+C(1-\alpha) A L^{\alpha} C^{-\alpha} \quad$ (4)

$Q_{t}=\alpha A L^{\alpha} C^{1-\alpha}+(1-\alpha) A L^{\alpha} C^{1-\alpha}$ (5) and $Q_{t}=\alpha Q_{t}+(1-\alpha) Q_{t}$ (6). The long run total outlay equals the long-run total revenue! But no matter product price!

${ }^{2}$ Meaning nothing is gained above normal profits.

${ }^{3}$ Given that $Q_{t}=\mathrm{d} Q_{t} / \mathrm{d} C_{t} * C_{t}+\mathrm{d} Q_{t} / \mathrm{d} L_{t} * L_{t}$ (7), or if $Q_{t}=M P_{c} * C_{t}+M P_{l} * L_{t}$ (8) holds, the pro-

duction function is homogeneous of degree one.
} 
Douglas (1976) re-visited "the 1928 Cobb-Douglas production function", mentioning its history, its testing and giving certain new empirical values. The Cobb \& Douglas (1928) found ${ }^{4} \alpha=0.6$, and till $1938=0.65$. Further, they estimated the results for fixed capital and physical production. In 1937, function (1) changed to: $P=b L^{k} C^{j}$ (9). Again, $k$ found 0.65 and $j=0.33$, using time series. Then the Cobb-Douglas research used the cross-section method, and applied it to individual industries (1904-1919, on discrete years), $\mathrm{k}$ found to vary from 0.65 to 0.66 , and $\mathrm{j}$ from 0.31 to 0.32 , over 1,450 observations.

Research resumed in 1956-1968, (the years were not continuous), over 160 industries and 1123 observations, and $\mathrm{k}$ found within 0.54 to 0.61 . The two coefficients together were equal to 1 only in 1967 . We have but to admire Cobb and Douglas, and especially Douglas, for his persistence in research for proving the constant economies of scale for a period of over 50 years!

As argued by certain economists (Hahn \& Matthews, 1964: p. 379) technical progress is embodied in new machinery, and bear the technology of their date of construction or machines have a birth date or vintage (Goulielmos, 2021a). The new machinery consists a separate family with own production function! The manna, in the form of technical progress, falls only together with new machines. This is called "new approach" (and it had to be distinguished from the “orthodox" one).

One may ask: how a capital equipment, like a vessel, of unchanged size, and the same quantity of crew, upon delivery, can produce more? The answer is mainly by a newly built larger ship, with an increased speed, installing a more powerful main engine, due to technical progress...

In shipping, finance, i.e., the monetary capital is the one, which is transformed into fixed capital, which is a necessary, and also a dominant condition to make business, and thus the shipowner has the right to get lion's share, or $50 \%$ of the annual cost, as he/she is the one to find a loan, either from commercial banks or from Stock exchanges.

Alderton (1999) argued that between 1950 and 1970, a typical dry cargo vessel, run between Europe and Australia, increased her size from 13,066 dwt to 15,473 (18.4\%), her speed from 13 knots to 15 (15.4\%) and... her daily consumption from 20 to 24 tons, but her voyage time reduced from 217 days to $213 \ldots$

\section{Aim and Structure of the Paper}

This paper has 4 main aims: 1) To estimate the coefficient b in the Cobb-Douglas production function: $P=b C^{1-\alpha} L^{\alpha} \quad$ (where $b, 1-\alpha$ and $\alpha$ are constants $>0$ ); 2) to provide a historical account of the technological progress in shipping, after 1945; 3) to determine the production of the: a) vessel, b) shipping company and c) maritime industry, relating it to its technical progress, and 4) to estimate the physical value of shipping technical progress, but also the $\$$-value of it. This last one makes more sense for managers and is a unique contribution of this work.

${ }^{4}$ They calculated an index of the number of manual workers in 1927 USA manufacturing, covering 1899-1922. 
The paper is made up by parts, after literature review and methodology. Part I deals with the history of the technical progress in shipping, 1945-2021; Part II deals with determining the framework of production in shipping industry; Part III deals with the production of tankers, 1963-2005, and Part IV deals with estimating technical progress in shipping in physical and monetary terms. Finally, we conclude.

\section{Methodology}

Equation $^{5}$ (1) will be used generalized, i.e., putting $1-\alpha=\beta$ (10). Also, $b=A_{t}$ (11). So, Equation (1) now becomes: $P_{t}=A_{t} C_{t}^{\beta} L_{t}^{\alpha} \quad$ (12), where $P_{t}$ is current production, $A_{t}$ is a coefficient, which may increase current production due to changes in factors, other than Capital quantity, $C_{b}$ and Labor quantity, $L_{b}$ i.e., due to technical progress.

The above equation allows also to find-out all 3 cases of returns to scale: constant, increasing or decreasing. If $f(\lambda C, \lambda L)=\lambda^{n} f(C, L)$ (13) and if $n>1$, there are increasing returns to scale (Jacques, 2018: p. 168), meaning that by increasing capital and labor by $\lambda$, production increases by $\lambda^{n}>1$. Of exclusive importance for this paper will be coefficient $A_{t}$ indicating the state of technical progress in production, at time $t$, showing the efficiency derived from technology!

This can be shown: let $C_{t+1}=C_{t}=1$ (14) and $L_{t+1}=L_{t}=1$ (15), meaning constant quantities of Capital and Labor in production, then by Replacing (1) becomes $P_{t+1}=P_{t} * b * 1 * 1$ (16). This further means that by keeping $C_{t}$ and $L_{t}$ constant, we can increase production by $b\left(=A_{t}\right)$ ! A miracle? If managers knew this miracle, they would appreciate more the role of TP!

\section{Part I: The History of Technical Progress in Shipping, 1945-2021}

\subsection{The Events, 1945-2021}

All businesses take place within the historical time, and not in a vacuum. The events that occurred in the years after $2^{\text {nd }}$ World War, are only shown (drawn on Beenstock \& Vergottis, 1993; Hughes, 1996; Alderton, 1999; Buckley, 2008; Stopford, 2009) (Table 2).

For the time being, and from all the above main important technological advances, we may say that the increase in oil prices in end-1973 was the decisive factor for shipping, not only because increased the cost of fuel consumed by ships, but also because it diminished the consumption of oil worldwide, and many countries tried to find their own sources of energy! In addition, the cost of living increased, because all economies were, and are, oil-dependent and electricity-dependent which even this is produced by diesel.

${ }^{5}$ Closer to shipping, where "land" does not get involved, and sea is free with the exception of crossing canals and calling at ports. 
Table 2. Events after 1945, and technological advances till 2021.

\begin{tabular}{|c|c|c|c|}
\hline Event, the & Event, the & $\begin{array}{c}\text { Technical } \\
\text { developments }\end{array}$ & $\begin{array}{l}\text { Technical develop- } \\
\text { ments }\end{array}$ \\
\hline $\begin{array}{l}\text { Korean War } \\
1950-51\end{array}$ & Gulf War, 1990 & Anti-fouling paints & $\begin{array}{l}\text { Bigger ships by } \\
1995>100,000 \mathrm{dwt} \\
\text { Capes }>100,000 \mathrm{dwt}\end{array}$ \\
\hline $\begin{array}{l}1^{\text {st }} \text { Suez Canal } \\
\text { closure-1956-1957 }\end{array}$ & Iraq invasion, 2003 & $\begin{array}{l}\text { More efficient diesel } \\
\text { engines-more } \\
\text { efficient engines } \\
\text { in general }\end{array}$ & $\begin{array}{l}\text { Specialized vessels; } \\
1975 \text { emerged }\end{array}$ \\
\hline $\begin{array}{l}2^{\text {nd }} \text { Suez closure } \\
1967-1975\end{array}$ & $\begin{array}{l}\text { Global financial crisis } \\
\text { end-2008-2018 }\end{array}$ & $\begin{array}{l}\text { Improved } \\
\text { hatch covers }\end{array}$ & $\begin{array}{l}\text { Improved on-board } \\
\text { technology }\end{array}$ \\
\hline $\begin{array}{l}\text { Yom Kippur War } \\
1973-1^{\text {st }} \text { oil crisis }\end{array}$ & Pandemic 2019-2022 & $\begin{array}{l}\text { Unmanned engine } \\
\text { room, early } 1960\left(^{*}\right)\end{array}$ & Satellite navigation \\
\hline $2^{\text {nd }}$ oil crisis, 1979 & & $\begin{array}{l}\text { Better organizing } \rightarrow \\
\text { computerization; } \\
\text { digitalization }\end{array}$ & $\begin{array}{l}\left.{ }^{*}\right) \text { Automation in } \\
\text { machinery spaces }\end{array}$ \\
\hline $\begin{array}{l}\text { Economies of scale } \\
\text { recognized, 1955- }\end{array}$ & $\begin{array}{l}\text { Air pollution } \\
\text { control-scrubbers, } \\
2011-2021\end{array}$ & New ship-designs & $\begin{array}{l}\text { Reduced manning } \\
\text { cost due to 1981-1987 } \\
\text { depression }\end{array}$ \\
\hline $\begin{array}{l}\text { Energy } \\
\text { conservation } \\
\text { measures: 1974- }\end{array}$ & $\begin{array}{l}\text { Use of alternative } \\
\text { fuels more friendly } \\
\text { to environment than } \\
\text { oil \& coal }\end{array}$ & $\begin{array}{l}\text { A Diesel engine } \\
\text { design appeared }\end{array}$ & \\
\hline
\end{tabular}

Source: inspired from Stopford (2009), p. 119 \& after; Hughes (1996), chap. 12.

\subsection{Technical Progress as a Tool to Solve Shipping Problems}

We believe that, in shipping, technical progress was called to solve major problems of the industry (Graph 1).

As shown, the major problems that had to be solved were that ships had to become larger; the ship engines had to be more economical by consuming less fuel; ships had to be more suitable to cover larger distances, and more recently ships had to reduce air pollution caused by ships' engines.

Shipowners, and Onassis, understood well the benefits of scale economies, especially after Suez Canal closures, and distances' lengthening. In addition, shipowners had to face a very expensive fuel oil, and this could be done only by new engines, and/or by a cheaper fuel! The scrubber is a rather recent invention, quite expensive ${ }^{8}$, emerged when ships found to pollute air.

As shown, the 7 challenges were specific and provided a chain reaction so to

${ }^{6}$ The propulsive performance of a modern vessel, during mid-1971-mid 1996 (25 years), reached a high level. In mid-1996 the "derated main engine" $\left({ }^{*}\right)$ emerged, but it was expensive. During this period, a quite remarkable improvement occurred in the performance of the so-called conventionai propulsion systems. $\left(^{*}\right)$ Method used to increase the "thermal efficiency of a main diesel engine" by maintaining the maximum combustion pressure (by design).

${ }^{7}$ A major technical innovation was that used to close ship's hatchway water tightly. There are available 6 types (Brodie, 1991). Their operation is hydraulically.

${ }^{8}$ Perhaps $\$ 1 \mathrm{~m}$. 


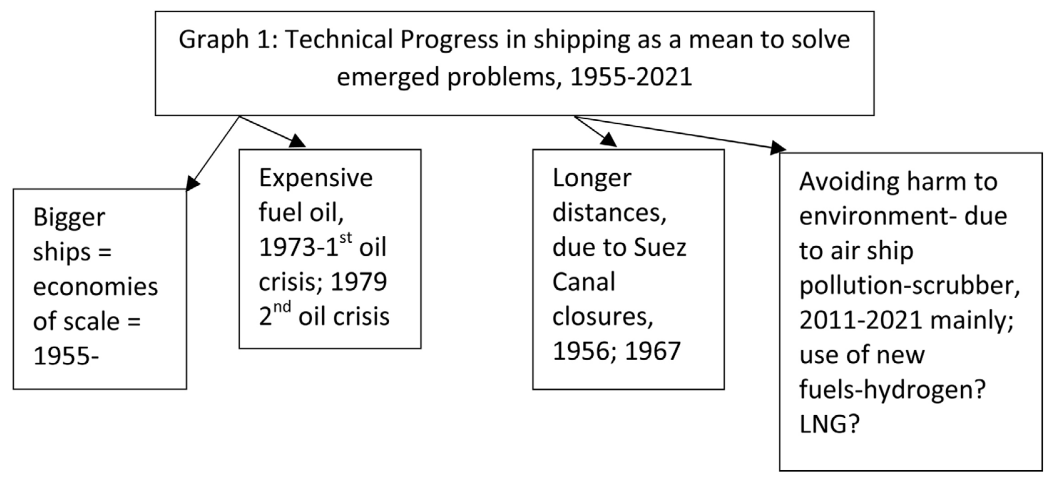

Graph 1. Technical progress in shipping as a mean to solve emerged problems, 1955-2021. Source: author.

say: economies of scale required by the greater volumes of sea trade, meant bigger ships, which required more powerful engines-capable also for an increased speed. The increased speed required also by the emerged longer distances. To the above expected normal changes, the severe challenge of a very expensive fuel emerged! The fuel used by ships received a double increase in price! Old ship engines were designed with an internal cheap fuel in mind, which after 1973 and 1979 was not the case, till this day. Normal were also the changes as far as new designs of ships with reduced friction of the hull in the sea etc. are concerned.

The history of technical innovations that have occurred in shipping is remarkable as well fascinating, with an always focus on "fuel" as to how to move the vessel: first was the wind, then steam and then diesel, where the target was always to reduce crossing time. Time is money they say! Today, engineers regretted because they have adopted fuel oil at the end of $2^{\text {nd }}$ World War as fuel-as being the main polluting substance...causing the climatic collapse... The Revenge of fuel oil has been accomplished!

Technical progress in ships more frequently than not, and during recent years, par excellence, focused also on the type of fuel oil likely to be used, which would be more friendly to air environment! People today see the most tragic way the impact of the climatic destruction with fires (USA), and floods in Europe (Germany, Belgium, the Netherlands etc.). The revenge of the rivers is also realized!

Next, we will present above issues following the order of Graph 2.

\subsection{Economies of Scale-The Size of Ships}

The standard vessel ${ }^{9}$, after $2^{\text {nd }}$ World War, was the 10,000-dwt dry cargo (bulker, with tween decks $^{10}$ ), named: Freedom ${ }^{11}$, Liberty ${ }^{12}$, Fort, Empire and Victory ${ }^{13}$;

${ }^{9}$ These ships had a "steam reciprocating engine" with "oil fired boilers", with a loaded speed of about 10 knots, and a high ( 35 tons) fuel oil consumption!

${ }^{10}$ Popular type of general cargo vessel with holds divided horizontally by 1 or more decks. They increased in size by 1991 to $18,000 \mathrm{dwt}, 15.9$ service speed, 4 holds, and 3 cranes of $25 \mathrm{t}$ each.

${ }^{11}$ The "freedom" ships ranged from 14,800 to $15,600 \mathrm{dwt}$ at 13.5 and 14.5 knots speed.

${ }^{12}$ With water tube boilers.

${ }^{13}$ “Turbine driven" for a somewhat larger dwt and/or a higher speed. 
Graph 2: Areas in which technical progress had to help ships, after 1945

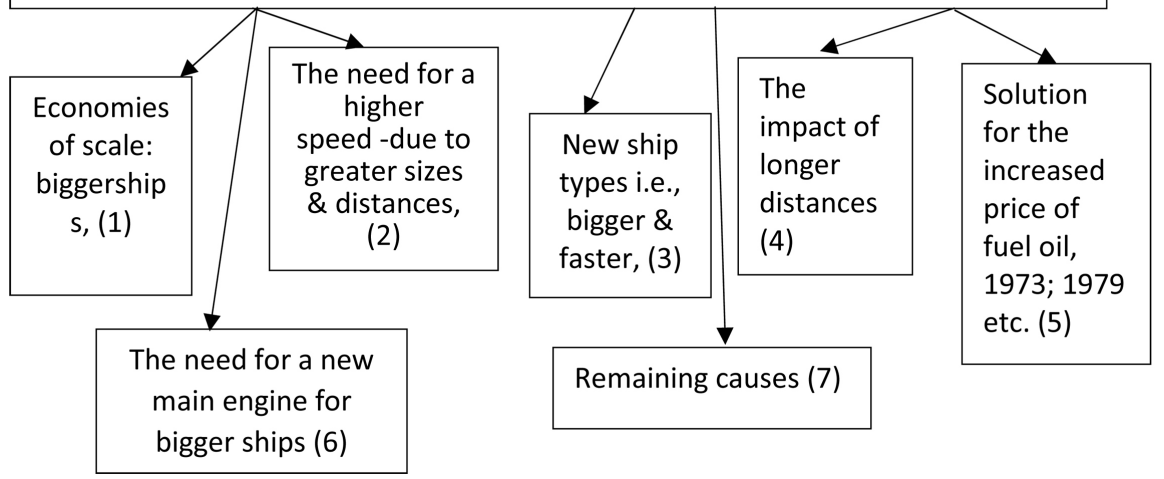

Graph 2. Areas in which technical progress had to help ships, after 1945. Source: author.

the T-2 tankers were slightly larger ${ }^{14}$, with turbo-electric machinery; their main engine drove the propeller, when in sea, and the cargo pumps while in port!

The year 1955 marked the beginning of the rather massive shipping economies of scale (Goulielmos, 2021b) in both tankers ${ }^{15}$ and bulk carriers ${ }^{16}$. The size of the tankers stabilized at around 540,000 dwt in 1970-1980. Bulk carriers stabilized too, and theirmid-1996 maximum dwt was 350,000 (Very large bulk carriers), carrying iron ore from S. America to Japan.

Then, the 400,000 dwt bulk carriers were built, called the "Vale" bulk carriers aimed at carrying iron-ore to China (Scan 1). We all are aware today of the tankers called VLCCs (very large crude carriers) and ULCCs (ultra large crude carriers), varying from $100,000 \mathrm{dwt}$ to $350,000 \mathrm{dwt}$ and from $350,000 \mathrm{dwt}$ to $550,000 \mathrm{dwt}$ respectively!

\subsection{A Higher Speed?}

As understood so far, the solution for larger ships and longer distances was speed! As shown (Figure 1), in order to increase ship's speed from 10.2 knots to $12(18 \%)$, a shipowner needs to increase the "break horse power" by $50 \%$, and the daily consumption from 9 tons to 18 !

As shown, going from 12 knots to 14, the oil consumed approached almost a double figure. The fuel cost is the new headache for shipowners and they may cover $47 \%$ of the voyage cost as between 1970 and 1985 fuel prices increased by 950\%. In 1985 this increased to $34 \%$. The rises continued in 2000 and thereafter. A Panamax bulk carrier at 14 knots consumes $30 \mathrm{t} / \mathrm{d}$. A $27 \%$ of the energy is used to cool the engine; $30 \%$ is in the exhaust emission; $10 \%$ by the propeller; $10 \%$ by hull friction and only $23 \%$ is used to move the ship! The above analysis gives 3 targets: main engine, hull and propeller. Between 1979 and 1985, with slow

${ }^{14}$ With no enclosed dock systems \& specific dimensions. $16,750 \mathrm{dwt}$ at $14.5 \mathrm{knots}$.

${ }^{15}$ In 1979 C.Y. Tung built the giant 569,783 dwt tanker (Hong Kong); 13 knots.

${ }^{16}$ The SD 14 vessel, became popular (emerged 1968); shelter-decker, 15,250 dwt, at speed 14 - $15 \mathrm{k}$., 5 holds, 5 hatches and lifting gear. A 5-cylinder diesel consuming $25.5 \mathrm{t}$ heavy oil/day, loved by Greeks. 


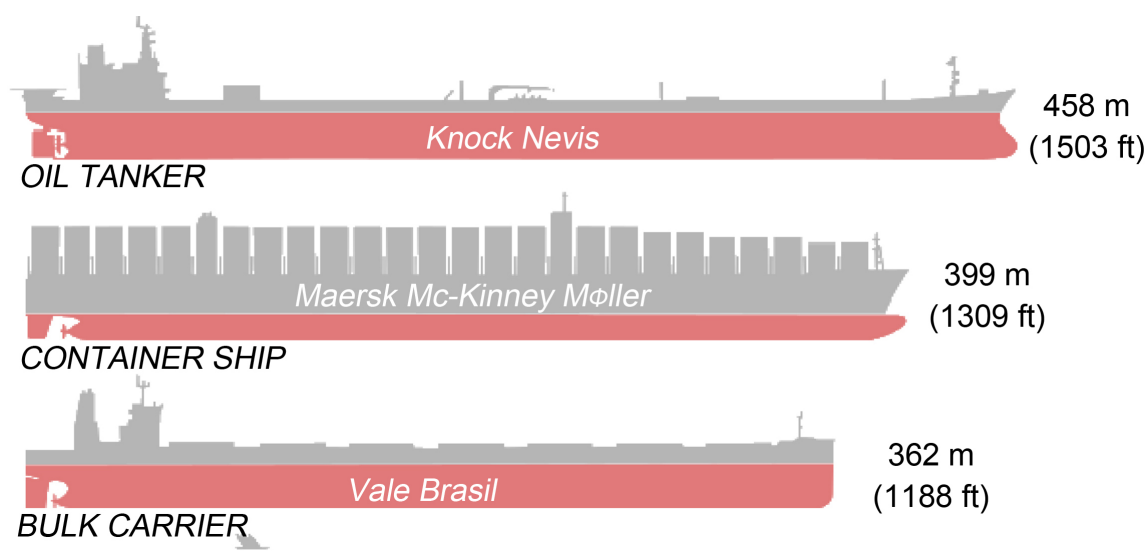

Scan 1. The largest ships among bulk carriers, tankers and containerships, 2012. Source: Wikipedia.

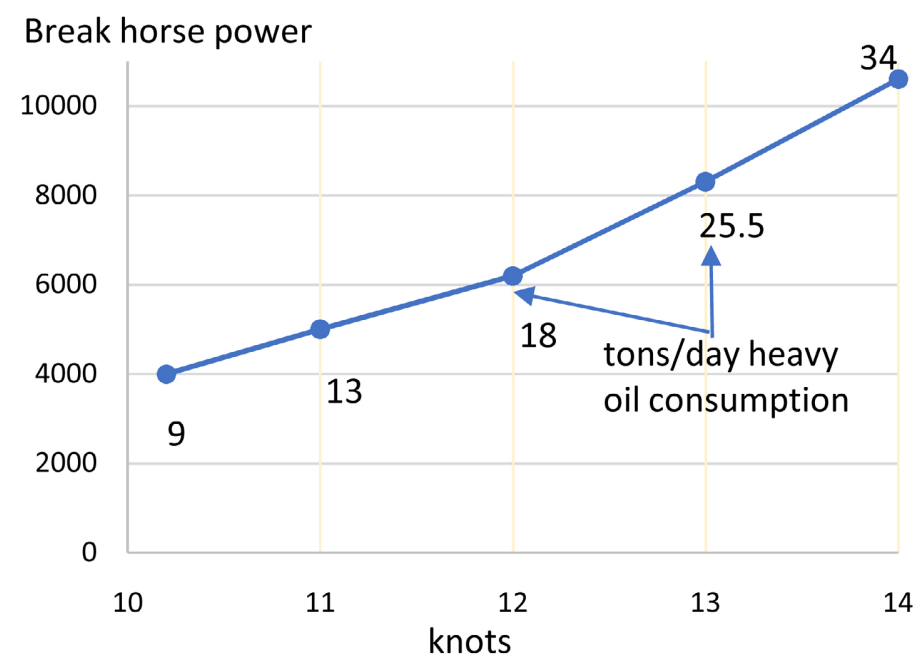

Figure 1. The speed of a loaded Panamax ship, built in 1995, at $15 \%$ sea margin. Source: author; data from $\operatorname{Hughes}^{17}$ (1996) (p. 88).

speed engines (less $100 \mathrm{rpm}$ ), we had 23 grams per break horse per hour and propellers of larger diameters. The results were spectacular!

\subsection{New Types of Ships: The Combination Carrier; The New Bulk Carrier}

A new type of drycargo ship emerged called "combination carrier". This was an experiment in ship flexibility, because she was designed to carry oil/bulk/ore, i.e., 3 cargoes in one (ship)! These were successful in 1950-1970 as new oil and dry cargo trades appeared. Their designs were two: 1) the "combi" carrier carrying oil and ore, which emerged in 1950-1960. 2) the oil/bulk/ore (ОВO), which emerged in mid-1960-1970. Leading Greek shipowners ordered OBOs, certain of them perhaps prematurely (Colocotronis Bros).

The above experiment was profitable, albeit only during tanker booms: 1967,

\footnotetext{
${ }^{17}$ Sea margin is the \% (usually $15 \%-20 \%$ ) difference between speed achieved during sea trials and that in actual service conditions, which are less favorable.
} 
1970 and 1973 (Stopford, 2009: p. 601-603). In 1975, the fleet of this type of ships reached $49 \mathrm{~m} \mathrm{dwt}$, but by 2007 fell down to only $8 \mathrm{~m}$.

The above idea was technological clever, but was not brilliant market-wise. The secret in the above ships is to find a return cargo, which did not always appear. Perhaps digitalization may solve this problem by registering cargoes anywhere in the sea world for the knowledge of shipowners. The ballast time is a quite expensive part of maritime business and waste of resources and technological progress which already exists in computer systems may help quite a deal in this area. Greeks too sold their combi ships after 1973. Carrying 3 types of cargoes, this vessel, could select the one paying most, and this was a further advantage! The combination carrier demonstrated the problem that vessels have, spending time in ballast, especially tankers... We revisit this issue below.

The 1960-1970 period was important, as a shipping technological innovation took place: "the new bulk carrier" (Picture 1). This was a single deck, larger by six times $(\sim 60,000 \mathrm{dwt})$ vessel. Her design provided scale economies from both operations and building costs and she provided a better return on price.

The ship, as shown, has 6 holds, 5 cranes, 12 top- and bottom-side tanks for ballast water and her engine room at stern; she has also "weather deck hatches". Her design economized on cargo spaces giving the most space to cargo, as it should.

\subsection{The Longer Distances}

One event which marked the $1^{\text {st }} d$ ecade of shipping after $2^{\text {nd }} \mathrm{WW}$, was the short 12 months $1^{\text {st }}$ Suez Canal closure in 1956-1957 (Beenstock \& Vergottis, 1993: p. 26-29). Despite its short duration, the closure influenced technical progress (!). This because it caused a rise in ship sizes and a considerable expansion of the order book (new production)! New ships, as mentioned, only bring new technical progress...

Many shipowners, and Onassis, but Gratsos C, (Goulielmos, 2021c), believed that the closure would be long, but it was not. This bad estimation, led shipowners to order ships suitable for almost a double distance (Figure 2 \& Figure $3)$. So, the first cause of technical progress was the1st Suez Canal closure in 1956 !

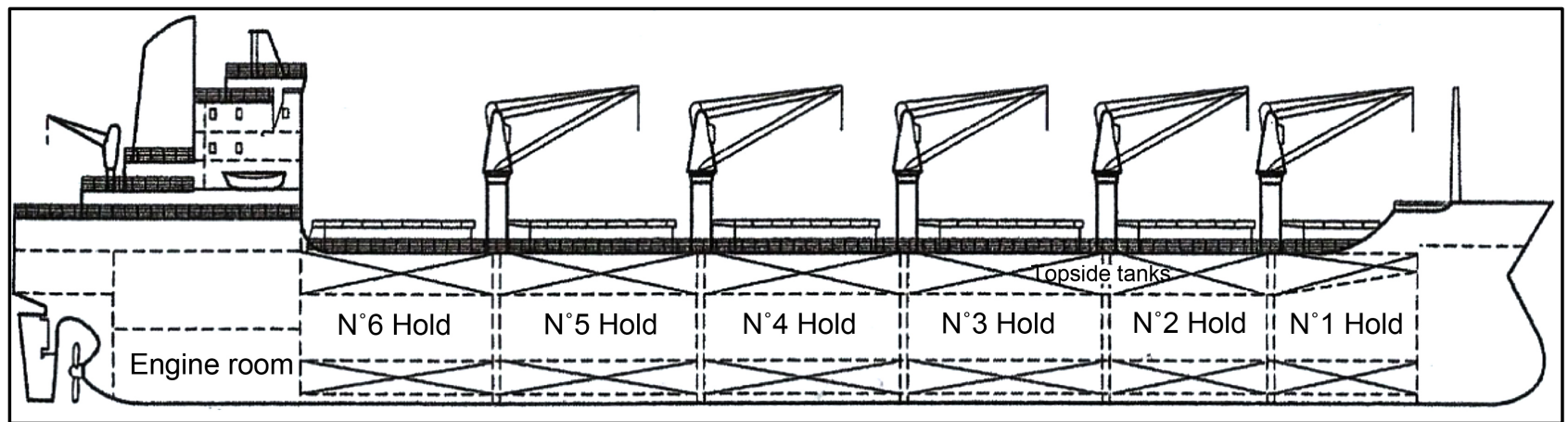

Picture 1. The 1960-1970 bulk carrier. Source: Modified from that in Branch \& Robarts. 


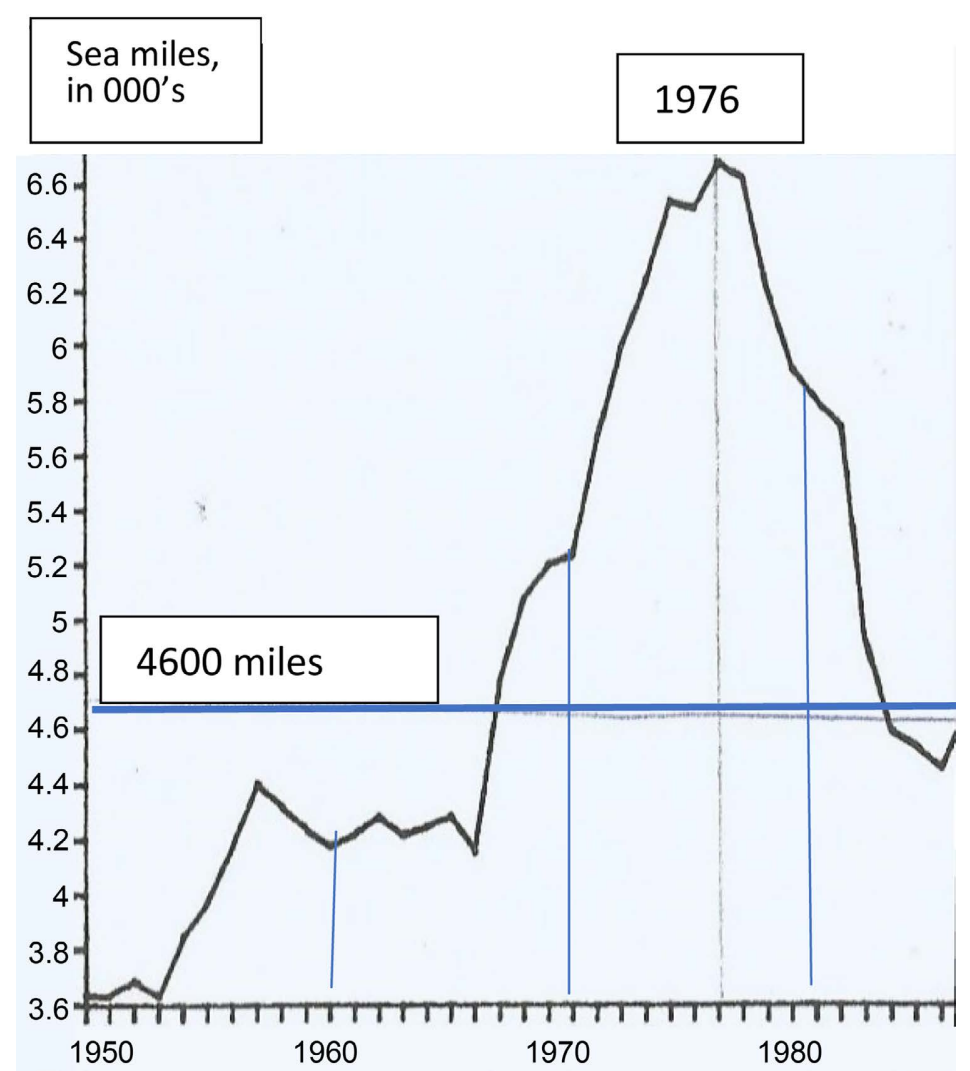

Figure 2. Average haul-length of oil shipments, 1950-1986. Source: author.

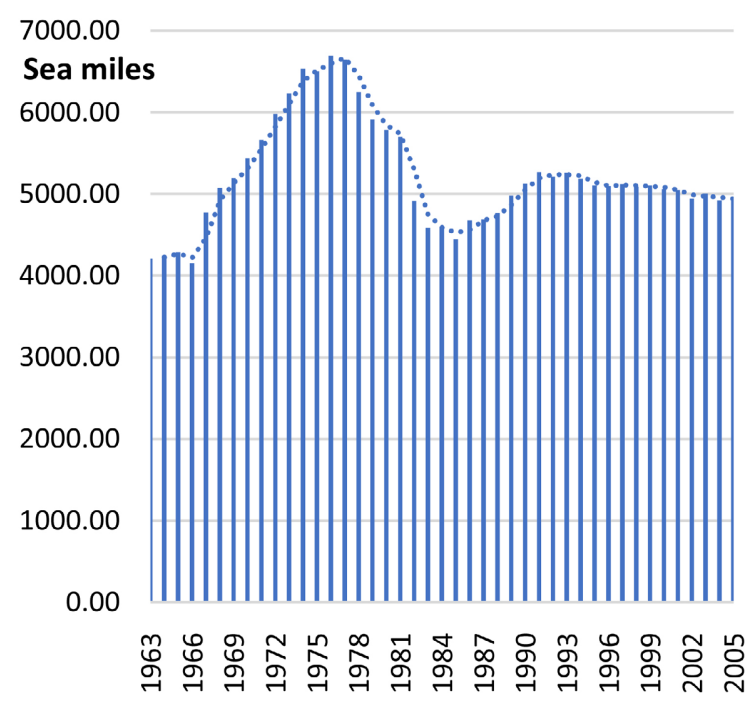

Figure 3. The Distances covered by tankers, on average, 1963-2005. Source: author.

As shown, between 1950, and 1953, distances for oil shipments were close to 3650 sea miles. Starting 1954, and especially in 1956-1957, when Suez Canal closed for the $1^{\text {st }}$ time, distances reached $4400(+20.5 \%$; 1955-1966) sea miles, and stabilized at $\mathbf{4 2 0 0}$ by 1966 . Then came the $2^{\text {nd }}$ Suez Canal closure in 1967, 
which was really long, lasting 8 years!

Canal closures followed the rule ${ }^{18}$ : "the longer the distance, the larger the vessel"! As shown, after 1966, distances exploded from 4200 to 6700 (+59.5\%), and in 1976-1977, tanker distances topped-up to 6695 sea miles! Then stabilized down to 5000 sea miles (2005).

Worth noting is that "distances" triggered an important technical progress in the form of, not only of bigger ships, but also of faster ones! Albeit, while the longer distances favored the ship economies of scale, and technical progress, oil prices took the revenge on behalf of Arabs, because fuel became a very dear commodity in end-1973!

\subsection{The Price of Fuel Oil}

The characteristic of the $1^{\text {st }}$ Oil crisis, (1973), was that the bunker prices increased 4 times $^{19}$, (from $\$ 20$ per ton) to $\$ 80$, and to $\$ 200$ (10 times) in early 1980-1990! The above means that the fuel cost increased from $\$ 1800 /$ day to $\$ 3600$ for the $\$ 200$ per ton ${ }^{20}$ price.

Unfortunate was the fact that due to Suez Canal closure, ships became bigger, before fuel becoming expensive! They gained also an extra speed of 1.8 knots/day, which increased their revenue! Arabs (OPEC, est. 1960), however, terminated the myth of the cheap, available to all, and abundant, fuel oil, and cancelled the total technical progress of ships obtained before 1973!

The maritime business environment turned to a new unwritten page, and a new history started to be written! Should shipowners expect such a revolutionary change? Should those who invented the private car imagine such a development at the start of the 1900 century? Should business men be proactive than reactive? Surely there was and other fuel available in 1900s. Oil was selected and proved to be detrimental to the world economy and unfortunately to global climate as well! Are business-men blind?

The cost of fuel (Figure 4) became a powerful factor, and since then (end-1973) prevented technical progress, as new bigger ships stopped to be ordered, and invited it, in another time, for a lesser fuel consumption or even for an alternative cheaper fue! This meant to "demand" from "ship engine manufacturers" to design an engine consuming either less quantity of fuel or a cheaper one and at higher speed!! A difficult puzzle!

As shown, in 1979, the oil fuel price more than doubled, till 1985, due to "Yom Kippur war", the "Iranian revolution" and the "netback pricing ${ }^{21 "}$ " OPEC, a cartel of governments, caused the rises in oil price. Between 1986 and

\footnotetext{
${ }^{18} \mathrm{We}$ believe that there is a chain relationship between distance, ship's size, speed and price of fuel, not always all to the same direction. In certain ships, the value of cargo determines also vessel's speed (e.g., in containerships). The longer distances imply fewer port calls, and thus a lesser port cost, given that the port cost depends on ship's dwt (or rather on GRT/NRT) i.e., on size! ${ }^{19}$ The "heavy fuel oil" emerged in 1950-1960.

${ }^{20}$ The "heavy fuel oil" in Rotterdam reached the mark of \$200 per ton in end 1980-mid-1981; and greater than $\$ 150$, from end 1979 till mid-1985.

${ }^{21}$ The price of oil after 1973 included all costs from extraction to buyer.
} 


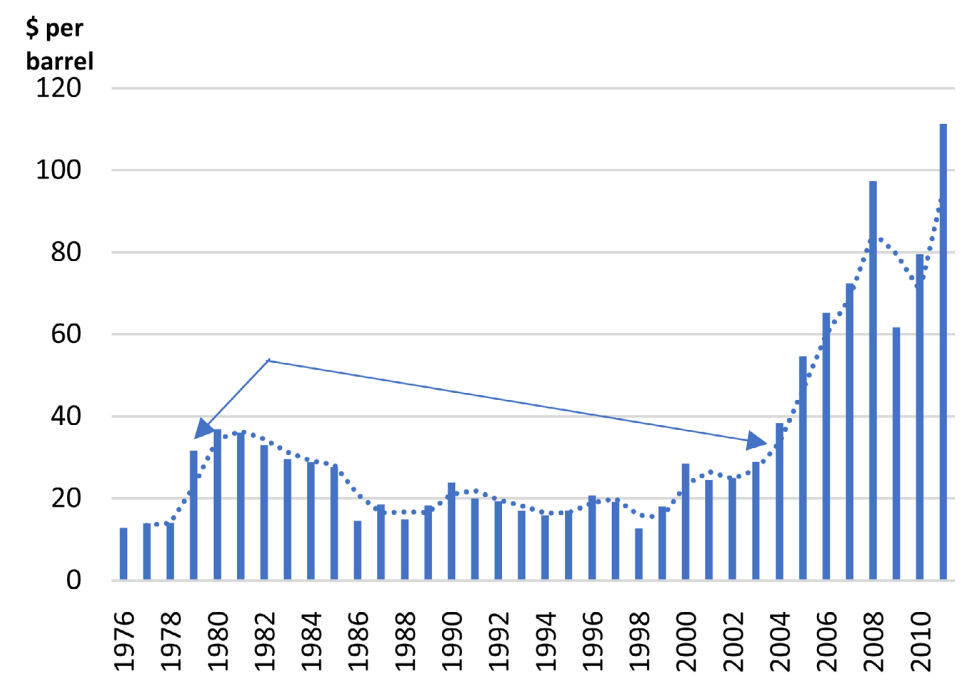

Figure 4. Spot crude oil prices in Brent, 1976-2011. Source: author; data from BP statistical Review, June 2012. (*) 1976-1983 forties; 1984-2011 Brent dated.

1999-with the exception of 1990: the oil prices fell near \$20. In 2000, however, an upward trend took place again for the oil price to reach $\$ 111$ by 2011! Pandemic in 2019 led oil price down to about $\$ 40$.

The reasons for seeking for a "better" fuel oil, are not the same each time. Recently everybody realized, we believe, and par excellence EU, as well USA after Trump administration, that environment is vital; and for us is the fourth factor of production, and we have to include it into production function, and pay the cost to preserve it (Goulielmos, 2020a, 2020b). Climate will revenge the un-clever man, who believed that he is more powerful than mother-Nature! Germany's 150 dead have proved this in July 2021.

When the fuel oil is expensive, the substitution law of economics holds, pointing to the use of even coal; and natural gas, methanol, hydrogen, schist, etc. Moreover, the expensive fuel oil triggered the so-called "energy reservation measures" for the first time! Nations embarked in finding their own sources of oil (North Sea; Alaska; Aegean etc.) and other sources more friendly to the environment. But the effort was not uniform and was in grave delay.

\subsection{Technical Progress in Main Ship Engines}

In 1945, the choice of a shipowner was among: 1) a reciprocating steam engine, 2) a geared turbine, with high-pressure steam, and 3) a moderately-powered $d i$ esel engine. Forty-five years later (1990), the choice was broader, among steam, diesel, and gas turbines; and among medium—or slow-speed engines-single or multiple engine systems, direct geared or with diesel-electric drive! The output derived, n 1990, was greater from 30,000 to 90,000 HP. Engine manufacturers faced successfully the challenges of the very dear fuel oil... we believe.

The problem of the doubled distances in one night, in 1956, was solved within 2 - 3 years, by building bigger and faster vessels. But the problem of "better" 
main engines was more difficult, and this required a longer time (1973-).

First, a cheaper fuel oil was used! Diesel engines replaced the steam ones, but they could not cope with the bigger ships! One technical progress ${ }^{22}$ (diesel engines) prevented by another (economies of scale) ${ }^{23,24}$. Technical progress embodied thereafter in a small \% of ships fitted with diesel engines ${ }^{25}$, with 12 tons only of diesel oil consumption! This was a great economy. This caused, however, the death of the steam turbine engines (Hughes, 1996: Chap. 12).

The reason for the above was that when oil prices are high, ship's speed is a very expensive factor, and the horse-power is lower; also, the "thermal efficien$\mathrm{cy}^{26}$ issue" emerged with diesel engines (then at $40 \%$ ). Steam engines were popular in tankers among USA and UK shipowners, but not among Norwegians.

The diesel engines ${ }^{27}$ had a high revolution propeller system compared with the steam engines (100 - 110 against 70 RPM, in a VLCC), and they were inefficient in propulsion. So, they were candidates for replacement!

A diesel-engine in a VLCC-built in 1976-covered 5.4 sea miles/ton of fuel oil, while one built round 1995, performed 7.7 miles (an increase of $\sim 43 \%$ ). This improved performance is considered as something typical (Hughes, 1996: p. 185) for most types of ships in mid-1996. This had an impact on total ship performance, given that fuel oil cost was 30\% of total annual cost (Buckley, 2008: p. $369)$ in 1980 !

\subsection{Remaining Inventions}

Another invention at the time was the self-trimming ${ }^{28}$ bulk carrier, important in the carriage of grain. The automation of machinery spaces, started in early 1960s, and led to the unmanned engine room. The 1981-1987 deep dry cargo shipping crisis revealed, as an expensive factor, labor on board for the first time! This caused flagging-out and the birth of the "European dual registries" (Goulielmos, 2020a, 2020b). Less labor quantity was in the target of ship designers all along, where in old times (1860) sailing ships had about 55 persons on board! Artificial Intelligence may present also the unmanned ship!

Technical progress in ships depends on technical progress in advanced indu-

\footnotetext{
${ }^{22}$ The low-speed diesel engines designed with a view to make the gearbox capable of reducing the propeller revolutions, especially with the medium-speed engines.

${ }^{23}$ The operation is on a 2 stroke (cycle) principle with crossheads \& guides transferring reciprocating piston movement via connecting rods into saft revolutions. Larger cylinder bores were as low as $260 \mathrm{~mm}$.

${ }^{24}$ The "crosshead" engines are distinguished from the "trunk piston ones".

${ }^{25}$ Steam engines were replaced by diesel engines made by Doxford, Harland \& Wolff, Sulzer B\&W and Gotarverken.

${ }^{26}$ "Derating" is a method to increase "thermal efficiency" of a main diesel engine. Here engine's reduced output is combined with maintaining the maximum combustion pressure (PMax). The "fully rated engine" had a lower unit cost vis-à-vis the "derated" one (i.e., \$/horsepower).

${ }^{27}$ The 2 stroke turbo-charging in early 1950s improved, by increasing the degree of turbo-charging, leading to a higher cyclic pressures and temperatures... and higher efficiency by $13 \%(40 \%+13 \%=$ $53 \%$ ), but expensive power turbines had to be provided. A "fully rated" engine can achieve $55 \%$ efficiency by increasing cyclical pressures.

${ }^{28} \mathrm{~A}$ ship whose holds are shaped in such a way so that a bulk cargo loaded into her will level itself.
} 
strialized countries, having also strong shipbuilding industries (e.g., USA; Japan; and others), and their customers, having expensive national crews, demand reductions in crew complement! So far, automation mainly in engine room, reduced labor on board worldwide.

Research into alternative fuels for marine propulsion is going-on today, including coal ${ }^{29}$, hydrogen, methanol, natural gas, and... plutonium in the past. Some have also used wind power as an additional push. This is the area were technical progress faces its largest challenge of the whole its history! A cheaper and more friendly to the air environment fuel for ships larger and faster? This will be the invention of all centuries!

\subsection{0. "Sea Time" Is the King, but "Port Time" Is the Queen in Shipping!}

If we want to select only one factor for ship's technical progress this is sea time, which depends mainly on speed. Another factor, of equal importance, if not higher, is port time, which depends on ports' (Table 3) technical progress.

As shown, an oil tanker gets a partial and lower, (39\% in \$ terms), benefit from her production, despite that her speed increased by $\sim 7 \%$ (rounded), and her sea time reduced by 2.78 days per voyage. However, the fuel consumed increased up to 5271 tons-at a price of $\$ 101 /$ ton, and over the same distance of 15,000 sea

Table 3. Time spent by ships at sea, in ports and in crossing canals depending on speed and port/Canal efficiency; on fuel quantity consumed, depending on speed; unchanged distances, 2008 .

\begin{tabular}{|c|c|c|}
\hline $\begin{array}{l}\text { Case } 1 \text { : distance } 15,000 \text { sea } \\
\text { miles (tanker: } 75,000 \mathrm{dwt} \text { ) }\end{array}$ & $\begin{array}{l}\text { Case 2: distance the same } \\
\text { (tanker: } 225,000 \mathrm{dwt})\end{array}$ & Remarks \\
\hline $\begin{array}{l}\text { Speed: } 14.5 \mathrm{k} / \text { day; } \\
\text { sea time } \rightarrow 43.1 \text { days }\end{array}$ & $\begin{array}{l}\text { Speed: } 15.5 \\
\text { sea time } \rightarrow 40.32 \text { days }\end{array}$ & Saving 2.78 days; $\sim 7 \%$ \\
\hline $\begin{array}{l}\text { Port time: } 4 \text { days; port cost: } \\
\$ 90,000\end{array}$ & $\begin{array}{l}\text { Port time } 8 \text { days; port cost } \\
\$ 360,000\end{array}$ & $\begin{array}{l}4 \text { additional days; } \$ 270,000 \\
\text { more cost! }\end{array}$ \\
\hline \multicolumn{3}{|l|}{$\begin{array}{l}\text { Canal transit time: } 2.25 \text { days } \\
\text { (Panama } 1 \text { day; Suez } 1.25 \\
\text { days) }\left(^{*}\right)\end{array}$} \\
\hline $\begin{array}{l}\text { Fuel quantity at sea: } 55 \\
\mathrm{mt} / \text { day plus } 5 \mathrm{mt} / \text { day at port } \\
\text { plus } 100 \mathrm{mt} \text { for other use, } \\
\text { total }=\mathbf{3 3 0 0} \mathrm{mt}\end{array}$ & $\begin{array}{l}\text { Fuel at sea etc. } 5271 \text { tons; fuel } \\
\text { cost at the same price: } \\
\$ 532,371 ; \% \text { on total cost: } 36.2 \%\end{array}$ & $\begin{array}{l}2471 \text { tons fuel oil extra; plus } \\
\$ 249,571 \text { extra! }\end{array}$ \\
\hline \multicolumn{3}{|l|}{$\begin{array}{l}\text { Fuel price: } \$ 101 / \text { ton }= \\
\$ 282,800 ; 30 \% \text { on total cost }\end{array}$} \\
\hline Total income $\$ 938,000$ & Total income $\$ 1,472,211$ & $\begin{array}{l}\$ 534,211 \text { extra income or } \\
57 \%\end{array}$ \\
\hline
\end{tabular}

Source: data from Buckley (2008), pp. 167-170, based on “Worldscale" calculations. (*) The Panama Canal charged to a ship, in 1992, of 60,000 dwt, \$68,000; the Suez Canal charged in 1992 to a 250,000-dwt vessel, $\$ 295,000$ (ballast); and in a vessel 60,000 dwt loaded charged \$135,000 (Alderton, 1999: p. 224)!

${ }^{29}$ The coal is mentioned in relation to a "coal fired steam turbine", or even a "steam reciprocating engine propulsion". Coal can be turned into oil. 
miles. The time spent in ports was longer -8 days against 4 and the cost of it was $\$ 360,000$ !

\section{Part II: Determining the Framework of Production in Shipping Industry}

What type of technical progress shipowners wish? TP in shipping is the one bringing inventions that make ship's production faster with bigger ships! We put this in two words: larger and faster! Worth-noting is that the contribution of Capital to production is dominant, in both, quantity and value, as mentioned. The complementary contribution of the Labor quantity, is comparatively smaller, as labor cost does not exceed $10 \%-15 \%$ of the total annual cost of the vessel.

The vessel produces only $95 \%$ of her dwt, if she is fully loaded. But even so, the vessel does not produce always, as shown in Graph 3, because there is: the "ship's time lost in off-hire operations"! We believe that the most efficient shipping manager is the one managing the time of ships in a rather perfect way! But do managers/Captains pay the attention that time deserves in ship operations? We doubt.

The ship's carrying-productive capacity is determined also by the weight of bunkers, water, stores, crew, etc., which restrict ${ }^{30}$ her $100 \%$ carrying capacity by

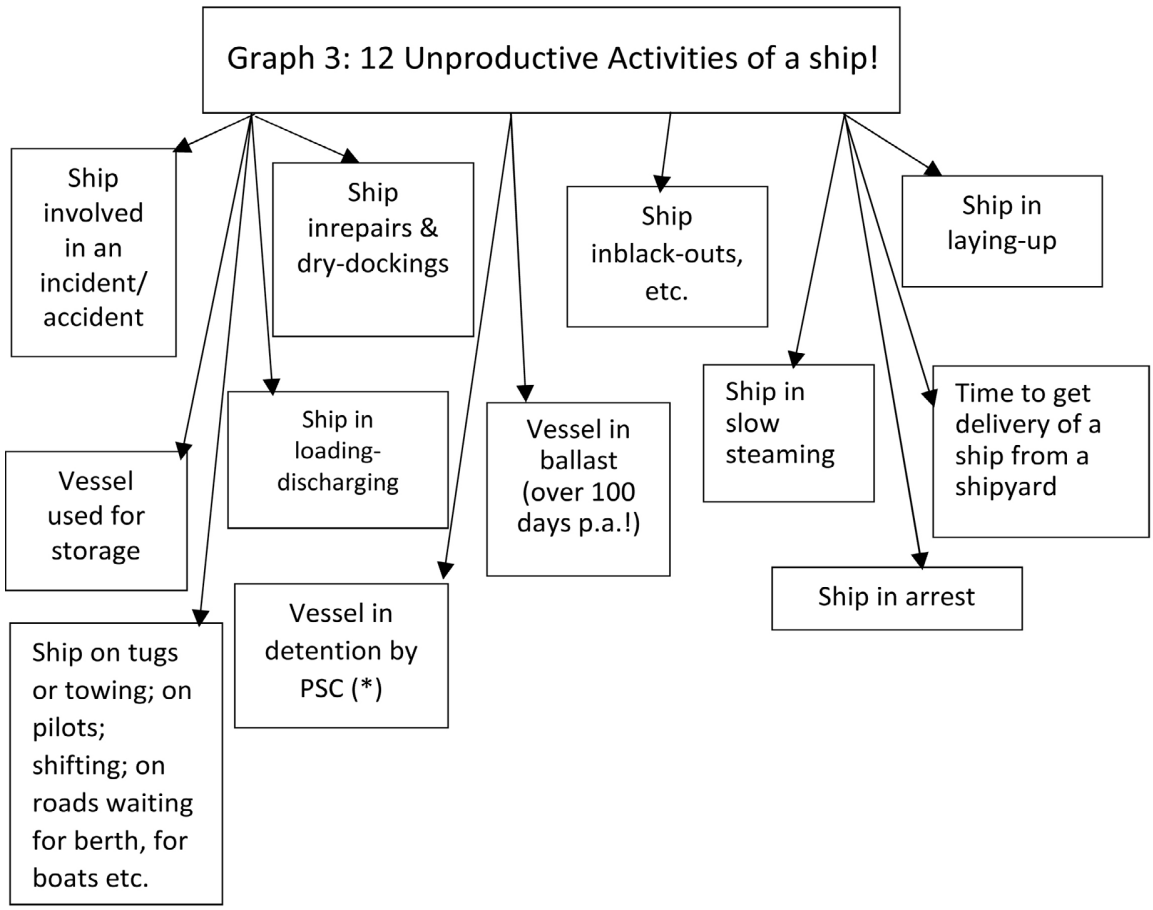

Graph 3. 12 Unproductive Activities of a ship! Source: Author; Stopford. $\left({ }^{\star}\right)$ IMO Port state control.

${ }^{30}$ Efficient Captains will optimize all items that reduce ship's carrying capacity so that these to be at a minimum possible. Captains may accept extra cargoes and gain an extra income for their company. The $5 \%$ of ship's dwt we assumed above is not fixed, and $2 \%$ of it may be saved, meaning a further income of $\$ 800$ per day in a freight rate of $\$ 40,000$, or $\$ 277,400$ p.a. for 346.75 days p.a. We may call this: the effort to optimize ship's cargo spaces. 
about 5\% on dwt on average... Stopford (2009: p. 155), presented a number of ship's activities, which provide zero production. We added to his list a few factors missed by him (Graph 3).

As shown, there are 12 causes that prevent a vessel to produce fully! An efficient management has to eliminate this time. This is a serious waste of resources both for the company, but also for the economy.

Stopford (2009: p. 155) calculated the time for 4 of the above factors (namely: incidents, repairs, laid-up \& storage), for a VLCC, in 1991, and found it equal to $21 \%$ or 73.5 days p.a. (on a 350-days year)! But, taking into account the loading/unloading and ballast time, the productive time of a VLCC is restricted to 140 days p.a. out of 350 (only 40\%)! We understand that a VLCC is difficult to find a return cargo, but these figures are terrifying for any efficient management.

The production of a vessel is determined by the distance she has to cross and of course by the speed applied by her Captain ${ }^{31}$. Distances cannot be influenced by shipowners ${ }^{32}$. The actual production of a vessel per unit period, will be affected also by the time required to cross canals (Suez; Panama; etc.). Many exogenous variables act in shipping, which have to be controlled...

Moreover, the port time affects also the present, but also the future ship production! The port time depends on the technical progress adopted by ports. This is true for gearless ships, i.e., those loaded/unloaded by port means. Port congestion is rather rare today, unlike $1975^{33}$, and Canals' blockades are also sporadic and we will ignore them, though we had an incident in March-July 2021 concerning Suez Canal with the giant containership "Ever Given" to block Canal's traffic for 3 months! An interesting question is who is going to pay Canals forgone transit fees?

Vessel's speed, however, remains the key-factor for ship's production for 3 main reasons (Graph 4). Managers have to decide about ship's speed ${ }^{34}$ after a careful study.

It is worth noting that shipping industry re-introduced time in economics (Goulielmos, 2018). One knot (1855.2 m) of additional speed makes a voyage faster by 2.78 days for a tanker of 225,000 dwt (Goulielmos, 2021b) for a 15,000 sea miles round trip. This time-saving per voyage, for one-year, amounts to 83.4 days, for 30 voyages per year, providing a serious additional production and revenue!

However, the port time increases also by 120 days (30 voyages $\times 4$ extra days) due to the higher quantity of crude oil to be loaded/unloaded! Apparently, tankers failed to increase the power of their loading pumps! So, benefits from a

\footnotetext{
${ }^{31}$ There are influences from weather, sea currents, swells, terrorism, piracy, etc.

${ }^{32}$ There is a program indicating the $2^{\text {nd }}$ best route, i.e., the most secure one. "Ship routing" services at a fee are provided with up-to-date weather predictions, avoiding storms, fogs, ices, etc.

${ }^{33}$ The Nigeria case of Lagos port waiting 3 months to discharge cement!

${ }^{34}$ The increase in ships' speed is more impressing, if we get long historical time. In 1870 a ship 2970

dwt had a speed of 7 knots; another, 5 times larger, had a speed of 15 k., 100 years latter!
} 


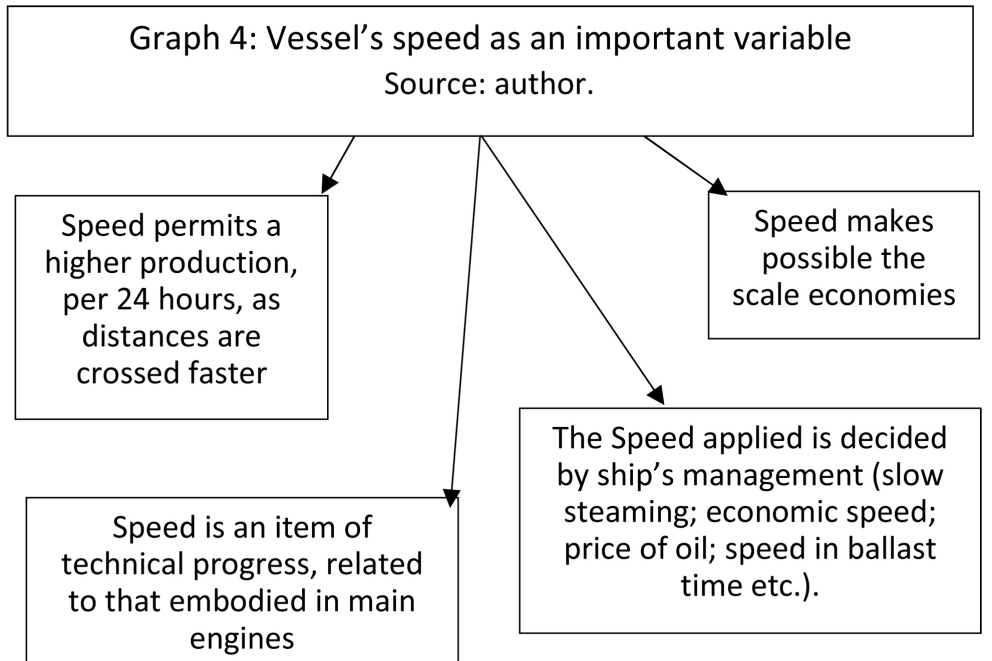

Graph 4. Vessel's speed as an important variable. Source: author.

higher size and an increased speed, can be cancelled by a longer port time!

Given that the cost of transport is paid by consumers, Governments had to push their ports towards additional technical innovation in reducing the time spent by ships across their production line, including receiving and discharging cargo and oil!

This paper has contributed by underlining this important target, we believe! The importance of time in shipping is further shown in Graph 5.

As shown, time is a very important technical, as well economic, factor in shipping business, which has not received the attention it deserved... But "latter is better than never". Ports should not hide under their carpet or behind their state or municipal nature, providing to them a monopoly ${ }^{35}$, but they have to adopt technical progress in advance of ships that my call... Otherwise the technical progress embodied in ships is done in vain... as we showed!

\section{Part III: The Production of Tankers, 1963-2005}

Idle productive capacity is another waste of resources in shipping. Figure 5 indicates the idle capacity, that crude oil tankers could put to production, for the recent 43 years, if demand supported them, and supply was more rational.

The above bad situation continued and after 1979, with the exception of 1980, and in 1981-1987. The sacrifice involved amounted in 1963 to $1.7 \mathrm{~m} \mathrm{dwt}$, but increased after 12 years, to $27.9 \mathrm{~m} \mathrm{dwt} \mathrm{(1975),} \mathrm{and} \mathrm{increased} \mathrm{more} \mathrm{thereafter,} \mathrm{be-}$ tween 1976 and 1979. In a tanker crisis, tankers are used for storage. They are also used to carry grain, after be cleaned. Unfortunately, tankers become also laid-up, when demand falls, like in 1975. In 1983 this idle capacity approached $70 \mathrm{~m} \mathrm{dwt!}$

As shown, the tanker sector was depressed in 1975, when oil seaborne trade

${ }^{35}$ Alderton (1999: p. 225) wrote that for the same ship in 1988 Finland ports charged $\$ 150,000$ while Lisbon only $\$ 12,500$ !!! How is this possible?? 


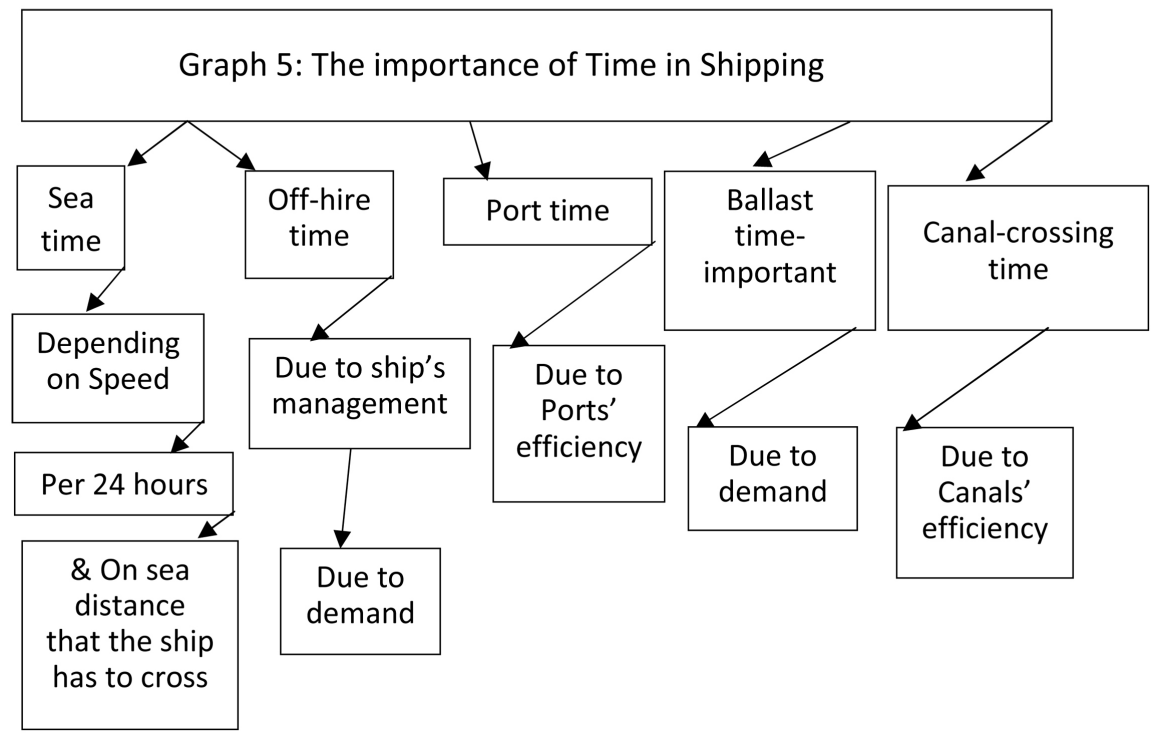

Graph 5. The importance of time in shipping. Source: author.

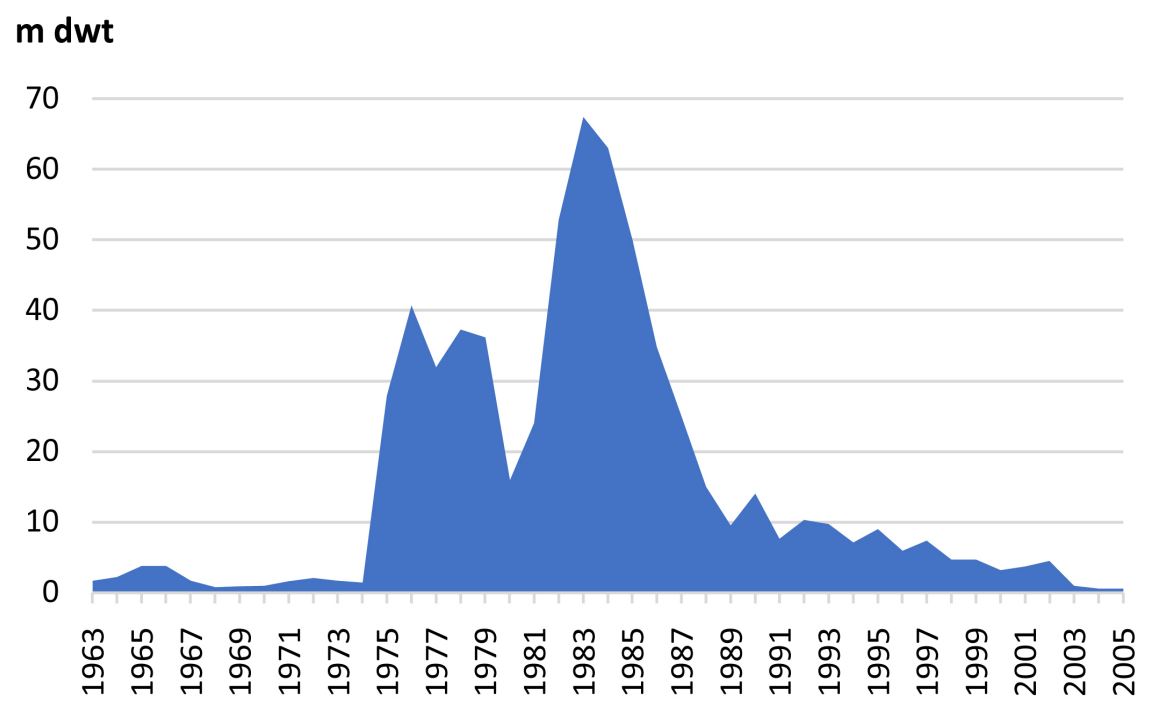

Figure 5. Tankers laid-up, in storage and in carrying grain, 1963-2005. Source: author; data from Stopford (2009: p. 748).

for the first time fell. This depression lasted till 1988 (12 years), while in 1980, it had a retreat. The relationship between demand for tankers and supply for them is shown in Figure 6.

As shown, the tanker demand had a cyclical behavior with a low in 1985 (blue line), while its decadence started in 1979. A part of the active tanker fleet (red line) served oil trade. The fleet responded to a higher trade between 1970 and 1980.

\section{The Productivity of Tankers}

More important of all is Figure 7, dealing with the tanker fleet, showing its productivity and Capital's marginal product! Unbelievable! 


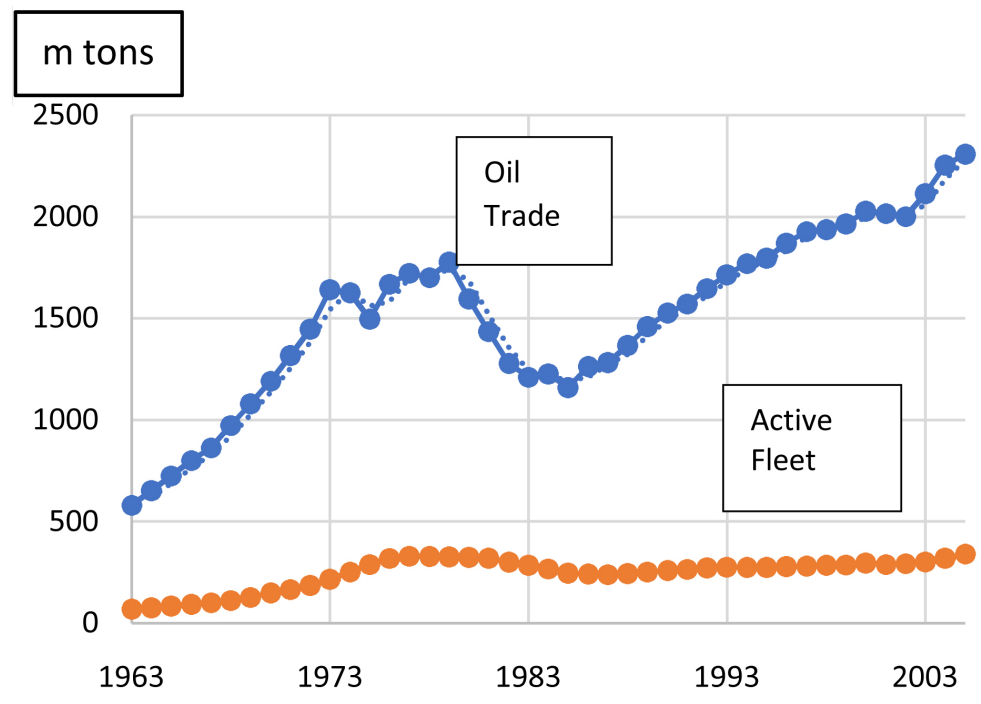

Figure 6. Supply and Demand for Tankers, 1963-2005. Source: Author; data from Stopford.

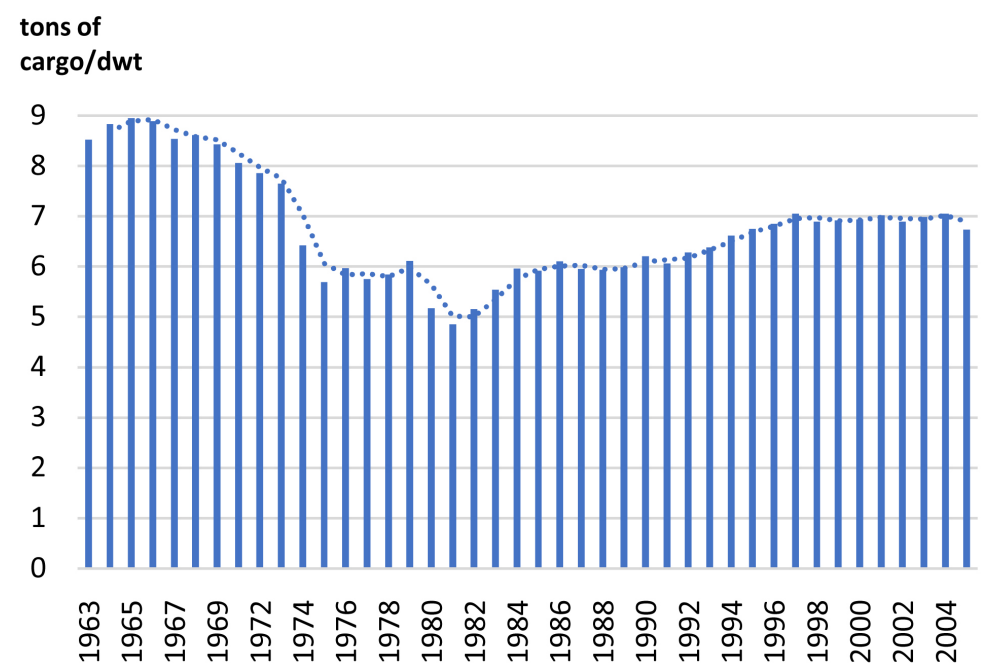

Figure 7. Tanker fleet productivity, tons per dwt p.a., 1963-2005. Source: author; data from Stopford.

Capital's marginal product $-\mathrm{MP}_{\mathrm{c}}-\mathrm{can}$ be defined as: the increase in capital quantity by 1 ton (dwt), and the increase in tankers' production. This was 8.95 tons (1965 top) of cargo carried, assuming a constant crew quantity. This $\mathrm{MP}_{\mathrm{c}}$ fell in 1967 to 8.54 tons, and to about 7, in 1997-2004. One may ask here: if technical progress increased tanker production, why fleet's productivity fell...?

Stopford informed us (p. 243) that ship's productivity depends on the: 1) average operating speed (per hour; and over 24 hours); 2) loaded days at sea p.a., and 3) dwt \% utilization.

The crisis in tankers, 1979-1987, reduced the loaded days at sea, and the \% utilization of ships. It is important to mention here that the role of demand, in the diffusion of technical progress, which comes from new buildings, is a key-factor. Thus, shipping depressions, discourage the order of new ships and 
thus the coming of technical progress, if it exists in shipbuilding. We wrote elsewhere that a research and development department is quite necessary in shipping companies, but we see it nowhere!

Ship productivity fell further from 6.11 to 5.95 tons (1979-1987). Technical progress pushed-productivity -up slightly between 1988 (5.93) and 1991 (6.06), where a heavy ordering of $55 \mathrm{~m}$ dwt took place; also, in 1995, the shipbuilding output over doubled from $15 \mathrm{~m}$ to $33 \mathrm{~m} \mathrm{dwt}$, proving our argument.

In ship's production distances, however, cannot be ignored (Figure 8). Above (in Figure 7), we calculated productivity free from the impact of distances.

As shown, distances increased in 1967, due to $2^{\text {nd }}$ Suez Canal closure (in May), for 8 years (till June 1975)! This had as a result bigger ships to be built, as distances increased by 2543 sea miles between 1966 and 1977. Thus, the major technological... invention, which took place, was to face the increase in distances by a subsequent increase in sizes of ships, and their speed! The importance of distances made us to present them twice.

Important for shipping is the cost of the raw material that is used to build ships, i.e., the steel. Shipping depends on so many other industries that they have to adopt technical progress too. The steel industry also passed through a series of technical developments (Besanko et al., 2013: p. 51). The steel industry initially produced high-volume products, suitable also for shipbuilding, where in early 1950s the lighter ${ }^{36}$ steel products emerged.

It has been used the so-called "basic oxygen furnace" (1950), the continuous

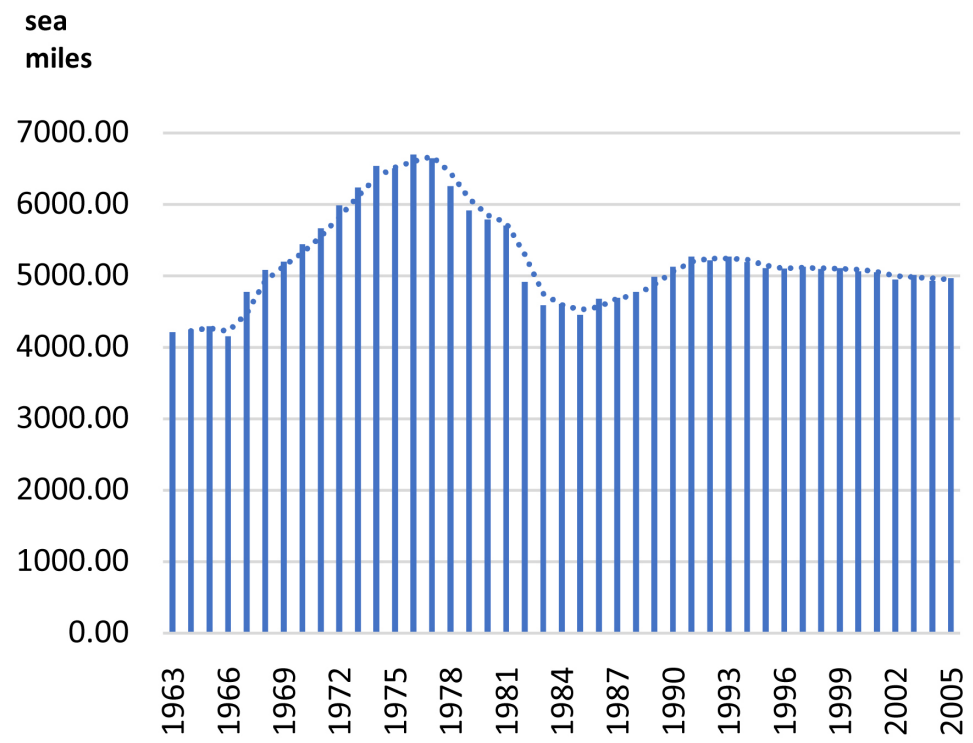

Figure 8. Distances covered by tankers on average, 1963-2005. Source: author, data from Stopford (2009: p. 748).

\footnotetext{
${ }^{36}$ The weight of the vessel is a serious factor in order to make ships faster and larger! Initially ships were made by iron. Moreover, iron plates were nailed one on the other and nailed down with ironrivets—additional weight. Ships, latter, were made of steel—a great TP—using electro-solderinganother great TP, and steel plates' soldering made one next to other without overlapping. Latter steel produced lighter-another technical progress.
} 
casting process (1960s) and the scrap metal processing, using the "electric arc furnace". In 1970 the scrap steel (due to discarded cars) introduced, followed by "mini-mills" (small producers) which converted scrap metal into finished steel products. In 1988, 93\% of all Japanese firms adopted the "continuous casting process". Modern societies produce millions of discarded cars, not taking into account useless ships. We are not sure if new material will be used in the construction of ships, but if this is lighter, cheaper and stronger, it will be of a technical advance.

Delivery of newly-built ships is the agents of technical progress, and as shown (Figure 9) in 1967, 1971 and 1977, this occurred. But deliveries did not exceed the $10 \%$ of existing fleet. Orders, at the same period, reached $23 \%$ maximum of the existing fleet, in 1957 (20.5\%), 1970-1971 (23\%) and 1975 (20.5\%). We see that deliveries are about $50 \%$ of orders, and there is a construction time between ordering and delivering.

In the $1^{\text {st }}$ semester of 2021 , almost $11 \mathrm{~m}$ "compensated gross tons" of ships ordered in e.g., the S. Korean yards, the bigger since 2008! Cgtis equal to $\mathrm{A}^{*} \mathrm{gt}^{\mathrm{b}}$, where A expresses the influence from the ship type. E.g., an oil tanker, with double hull, has $\mathrm{A}=48$, while a car carrier has 15 ; $\mathrm{b}$ states the influence from size and gt is the gross tonnage. For tankers this was, in 2005, 0.57 (Stopford, 2009: p. 752-754).

Our feeling is that shipping will expand enormously in 2021 and thereafter, trying to rectify the low growth rates since end-2008-2021.

To make our analysis complete, scrapping is also a positive agent of technical progress (Figure 10), because it removes old technology from market in a permanent way, unlike laying-up, which is a temporary withdrawal!

As shown, scrapping peaked in 1986 with $29 \%$ of the existing vessels of an age of over 15 years. We see that scrapping is almost 3 times higher than deliveries, meaning a reduction in fleets. In July 2021, the price of scrap steel reached $\$ 600$ per ton indicating an excess demand, perhaps due to the inactive period of the Pandemic!

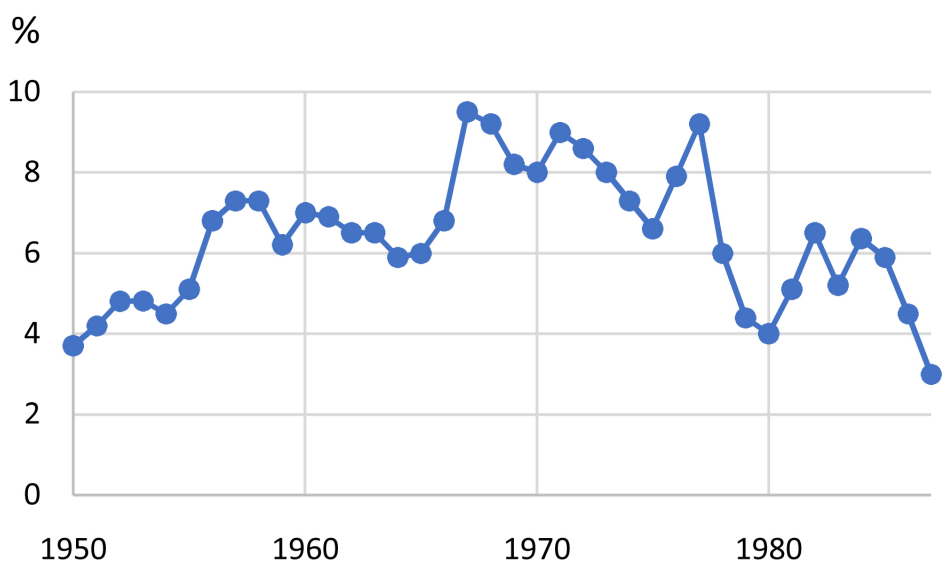

Figure 9. Deliveries of dry cargo ships as a \% of total fleet, 1950-1987. Source: author; data from Beenstock \& Vergottis (1993), p. 35. 


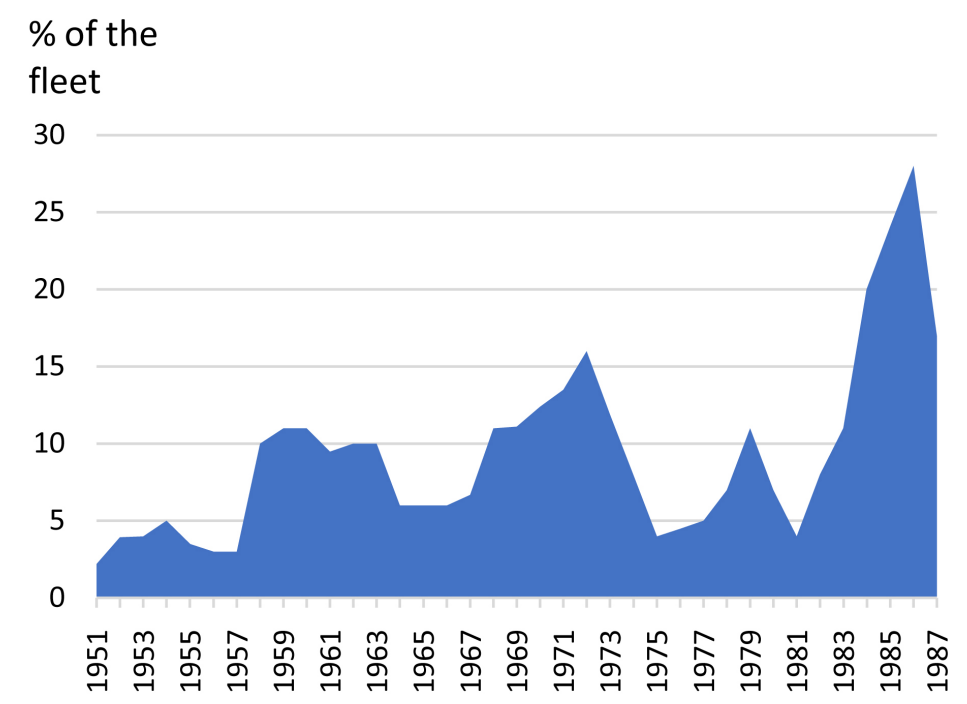

Figure 10. Scrapping, dry cargo, 1951-1987, ships of 15 years and over. Source: author; data from Beenstock \& Vergottis, 1993, p. 35.

\section{Part IV: Estimating Technical Progress in Shipping}

Now, we will try to perform two estimations: 1) shipping technical progress in physical (production) terms, i.e., in tons, and 2) shipping technical progress in $\$$ terms.

1) Let us take a newly-built tanker having a Capital quantity of 30,0oo dwt with a labor quantity of 26 persons, (data from Buckley, 2008: p. 369). She produces 28,200 tons per voyage. Her production function, in Cobb-Douglas form, therefore can be: $28,200 t=A_{t} 30,000^{\beta} 26^{\alpha}$. Assuming $\alpha=0.15$ and $\beta=0.94$, then $A_{t}=7.04 \%$. Given that $\alpha+\beta=1.09>1$, there are also economies of scale in tanker shipping.

The constant $\alpha$ put equal to 0.15 , given that this is the share of labor to total voyage cost; constant $\beta$ put equal to 0.94 as this is the share of capital to total voyage production. This means that with constant Capital and Labor, in shipping, a shipowner can produce about $7 \%$ more production due to existing and embodied technical progress!

Cobb \& Douglas (1928) found $A_{t}=1 \%$. Goulielmos (2021b) found ${ }^{37} A_{t}=7 \%$ for tanker shipping, where $t=2008$, due to a higher speed by 1 knot. Moreover, increasing capital quantity by 3 times, the tanker production increased by $5.5 \%$, (rounded), i.e., beyond the 3-time increases in Capital, on data from Buckley, 2008: p. 165-170), due to the bigger size of a 225,000-dwt tanker (Table 4).

2) Now, we will estimate the contribution of technical progress to shipping industry by finding-out the reduction in sea transport cost (freight rate) that achieved over the whole post $2^{\text {nd }}$ World War (61 years), using a deflated freight rate index found in Stopford (2009: p. 757-758). The signs of technical progress in shipping, as shown (Table 5), are four.

\footnotetext{
${ }^{37}$ This based on the increase of ship's speed by 1 knot. This meant a rise in average speed of a tanker from 14.5 knots to 15.5 knots or $+7 \%$.
} 
Table 4. Estimating technical progress in tanker chartering, 2008.

\begin{tabular}{lllll}
\hline $\begin{array}{c}\text { Change in } \\
\text { Capital's } \\
\text { quantity by: }\end{array}$ & $\begin{array}{c}\text { Change in } \\
\text { Labor's } \\
\text { quantity: }\end{array}$ & Change in Production & $\begin{array}{c}\text { Change in } \\
\text { speed }\end{array}$ & Technical progress \\
\hline & & & $\begin{array}{l}5.5 \% \text { more } \\
\text { production due to size; }\end{array}$ \\
$+150,000$ & Assumed & $\begin{array}{l}147,329 \mathrm{dwt} \\
(219,029-71,700) \text { due to } \\
\text { bigger size; } 15,102 \mathrm{dwt} \\
\text { dwt }\end{array}$ & $\begin{array}{l}+1 \text { knot; } \\
\text { benefit }\end{array}$ & $\begin{array}{l}15,102 \text { more } \\
\text { production due to } \\
\text { penstant }\end{array}$ \\
& & & $\begin{array}{l}\text { per voyage } \\
\text { speed } 10.25 \% \text { on } \\
\text { next production; total } \\
15.73 \% \text { benefit }\end{array}$ \\
\hline
\end{tabular}

Source: author; data from Table 3.

Table 5. Signs of main shipping technical developments, after 1945.

\begin{tabular}{lll}
\hline \multicolumn{1}{c}{ Signs } & \multicolumn{1}{c}{ Sign } & \multicolumn{1}{c}{ Sign } \\
\hline $\begin{array}{l}\text { Bigger bulker ships }>100,000 \\
\text { dwt (1995); Capes } \\
\text { emerged }>100,000 \mathrm{dwt}\end{array}$ & More efficient engines & $\begin{array}{l}\text { Specialized ships (1975): } \\
\text { a continuous \& pervasive } \\
\text { trend }\end{array}$ \\
$\begin{array}{l}\text { Improved on-board technology, } \\
\text { which led to unmanned engine } \\
\text { room }\end{array}$ & Result $\rightarrow$ & $\rightarrow$ Reduction of the cost of \\
\end{tabular}

Source: Inspired by Stopford.

The technical progress is encouraged by the existence of an adequate demand for the services produced! We did not fail to stress this reality... The post $2^{\text {nd }}$ war sea trade rose more than 6 times (from $500 \mathrm{~m}$ tons to 3.2 billion tons, 1950-1973). Shipping companies improved also their familiarity with computers, and especially with PCs. Recently adopted also digitalization (Goulielmos, 2020a, 2020b). Before we proceed, we need to prove the next question.

\section{Are Shipping Markets Perfectly Competitive?}

For the argument that technical progress led to a lower transport cost per ton for charterers, we have to prove first that shipping industry is competitive, because then price rests down on minimum average cost. We can say that shipping markets of dry and liquid cargoes are competitive, meaning that there are a very large number of small charterers and shipowners, acting independently, and no one can influence freight rate (price).

We know that in shipping exist, on average, about 10,000 shipping companies small, medium and large. About 70 large shipping companies are in the first 10 top maritime nations (=700) (Goulielmos, 2017), which can influence supply for orders of a few million dwt and over! In charterers, too, exist large influential companies like the 7 oil majors in the past. capable of influencing supply. We will assume that shipping markets are purely competitive, but not perfect.

Perfect competition is surely rare in real life, and it demands: 1) identical ser- 
vices $^{38}$, called homogeneous, with perfect information; 2) free entry ${ }^{39}$; this is more massive if profits are above normal; the free entry in shipping is important-and there is also a well-organized $2^{\text {nd }}$ hand ship market as when profits are above normal, new shipping companies enter, and normal profits are eliminated (Graph 6).

As shown, average cost equals freight rate in the long-run. As it is known, in the average cost, also normal profits are included. This is why people prefer perfect competition, as they pay the minimum possible, vis-a-cis imperfect markets! However, the average cost here is not only of the most efficient shipowner, but also of that of the "marginal" shipowner, who has the higher cost of all others!

So, competition provides the elimination of super (monopoly) profits, but not the elimination of high-cost firms, needed to satisfy demand! This means that new ships may be required to enter, but as shown elsewhere (Goulielmos, 2021a), is not guaranteed that the new ships have the lower total average cost (in the long run)!Worth noting is that competitive are not the newly-built ships, as most great economists, but Keynes, assumed for new machines! To be so, the newly-built ships have to have prices below the prices of the vintages before them! Then are more competitive. Greek shipowners know this...

Given our assumption that technical progress reduces the long run average freight rate (or cost of transport), using faster and bigger ships, and achieving shorter sea times, this, however, has to be confirmed by data (Figure 11) (Stopford, 2009).

As shown, the real (free of inflation) cost of sea transport, after reaching a top high in 1950-51, and in 1956, due to Korean War and the $1^{\text {st }}$ Suez Canal closure in 1956 fell down to 400 units, till 1972 (-60\% for 14 years). There was an interval between 1973 and 1974 , due to the $1^{\text {st }}$ oil crisis in 1973, when shipping was

\section{Graph 6: A competitive firm in equilibrium}

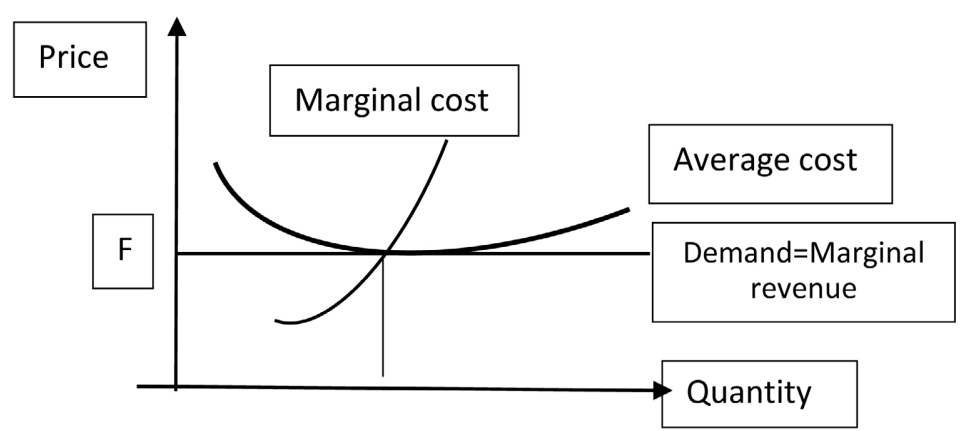

Graph 6. A competitive firm in equilibrium. Source: author.

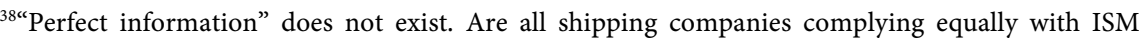
Code (an ISO maritime standard)? Are all vintages of ships equally safe?

${ }^{39}$ This assumes a rather low capital cost or low shipbuilding prices and low $2^{\text {nd }}$ hand ones and an easy access to shipping finance. The availability of finance and its level determines also the size of the vessel and her vintage! As ships get bigger, the sum to build or buy them gets higher and apart from risk, it becomes more difficult for medium and small companies to find it.
} 


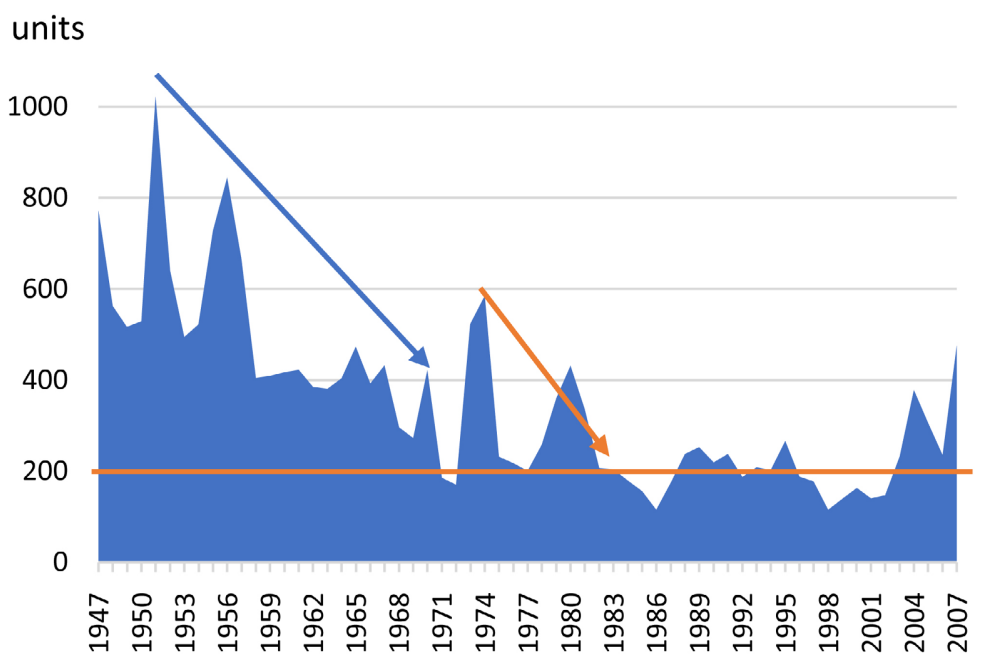

Figure 11. Maritime economics index 1947-2007, deflated by 2000 prices; $1947=772$. Source: data from Stopford (2009: p. 757-758).

producing at a higher sea cost, and then returned to 400 units' mark, continuously falling till 2006.

Given that a typical low sea cost is $\mathbf{2 0 0}$ units of the index, then technical progress reduced sea cost by 2.6 times in 1947-1970, and from 1971, with the exception of $1972-1974$, due to the $2^{\text {nd }}$ oil crisis in 1979 to 2007 , by 2.4 times, a total of 5 times. So, $A_{\mathrm{t}}=8.2 \%$ per annum (500\%/61 years) in money terms. Inflation excluded, but, 4 wars, 2 oil crises, longer distances, 2 Suez Canal closures, were taken into account! We wonder what the progress of shipping could be, if there was peace!

\section{The Research Significance and the Main Contribution}

All maritime economists have taken for granted that shipping industry is one of continuous technical achievements, but without providing proof for this in either physical or monetary nature. Apart from certain remarkable advances in ships' sizes, nothing has been discovered in the production function of the individual vessel despite the long existence of the celebrated Cobb-Douglas production function. First, we proved in a definite way that in shipping there increasing returns to scale, meaning that it pays to pursue economies of scale if demand exists. Further, we calculated the share of Capital and Labor in the production, with the lion's share to go to Capital, which is a right thing to see. The remarkable finding is that $8.2 \%$ per annum in $\$$ terms technical progress passed on to charterers, and perhaps from them to consumers. In physical terms $15.73 \%$ additional production has been provided by the innovations applied in tankers.

\section{Conclusion}

Analysis covered the last 75 years of technical progress in shipping industry, since 1945. One definition, and target, of technical progress, was to improve vessels' performance, and finally to reduce sea cost! However, the price of 
shipping services is determined in the first step by demand and supply, and the cost of shipping adjusts to it in a second step, following the rules of a competitive industry. Sea cost rests there down on long run average cost, free from monopoly profits.

An all-embracing factor reflecting technical progress in shipping was time spent in production. The advances in shipping technology, we believe, were in the right direction all along, and tried to achieve less maintenance, fewer crew, and lower shipbuilding cost! The last one is the most important! Economists assumed wrongly that new machines are cheaper (they are not due to a higher depreciation and profit requirements on capital invested).

As shown, using physical data of shipping production, and also monetary data, technical progress for the period of the last 61 years achieved a money benefit to world economy of $8.2 \%$ p.a., mainly aided by faster and bigger ships. In physical terms, production increased by $15.73 \%$.

Technical progress in shipbuilding, reducing ship prices, is of prime importance for shipping. Of course, the shipbuilding cycle, following the shipping one, will reduce prices of ships, liking it or not! One step of course is to produce a still cheaper and lighter, steel, but equally strong; another step is to reduce the building time using digitalization; a third step is to economize on materials, on engines etc.; a fourth step is to use cheaper, but skilled, labor, perhaps using educated females.

This paper produced important policy implications for ports for which also we added an appendix. Ports have to adopt technical progress at the pace that ships embody it! Otherwise, they harm ships. Ports must realize that they provide services to ships, and these services must be produced at lower cost than hitherto.

Ports from monopoly firms must become competitive ones. Ports achieved reductions in costs, but was this for own benefit, or for the benefit of ships? The gross average speed of cargo-handling, per hatch, all right increased from 80 tons/day in 1950 to 100 in 1970, but there is a large room for further improvements. Are port pumps for tanker unloading ${ }^{40}$ properly at 10,000 tons or so of petroleum per hour?

\section{Acknowledgements}

This paper was written by 3 friends, professors and colleagues, on the occasion that Professor Evangelos Sambracos-the third one-retired last on $1^{\text {st }}$ Sept. 2021! This paper should be considered as an "aide de memoir" to all three of us that the state of pension for a professor should not prevent him from writing papers!

\section{Conflicts of Interest}

The authors declare no conflicts of interest regarding the publication of this paper.

40"Louisiana offshore oil port" in 1981 processed more than $1 \mathrm{~m}$ barrels of petroleum ...per day! This copied by others, thanks God. 


\section{References}

Alderton, P. M. (1999). Port Management and Operations. LLP.

Besanko, D., Dranove, D., Shanley, M., \& Schaefer, S. (2013). Economics of Strategy (6th ed.). ISV, Wiley.

Brodie, P. R. (1991). Illustrated Dictionary of Cargo Handling. Lloyd's of London Press Ltd.

Buckley, J. J. (2008). The Business of Shipping (8th ed.). Cornell Maritime Press, Schiffer Books.

Chiang, A. C., \& Wainwright, K. (2005). Fundamental Methods of Mathematical Economics (4th ed.). McGraw Hill.

Cobb, C. W., \& Douglas, P. H. (1928). A Theory of Production. American Economic Review, Supplement, 18, 139-165.

Douglas, P. H. (1934). The Theory of Wages. Macmillan.

Douglas, P. H. (1976). The Cobb-Douglas Production Function Once Again: Its History, Its Testing, and Some New Empirical Values. Journal of Political Economy, 84, 903-915. https://doi.org/10.1086/260489

Goulielmos, A. M. (2000). A Proposed Shipping Policy to Counteract Flagging-Out: The Paradigm of Greece. International Journal of Maritime Economics, 2, 27-47. https://doi.org/10.1057/ijme.2000.5

Goulielmos, A. M. (2017). The Great Achievement of Greek-Owned Shipping (1946-2017) and Keynes' Animal Spirits. Modern Economy, 8, 1186-1210. https://doi.org/10.4236/me.2017.810082

Goulielmos, A. M. (2018). Time and Equilibrium: 2 Important, but Invisible, Concepts of Economic, with Application to Shipping Industry. Modern Economy, 9, 536-561. https://doi.org/10.4236/me.2018.93035

Goulielmos, A. M. (2020a). Society in Front of 2 Enemies: COVID-19 \& Climate Collapse/Their Impact on Shipping Industry. Modern Economy, 11, 2006-2026. https://doi.org/10.4236/me.2020.1112134

Goulielmos, A. M. (2020b). Management of Ships and Shipping Companies the Digital Way: What Is Ahead? Modern Economy, 11, 1263-1279. https://doi.org/10.4236/me.2020.117090

Goulielmos, A. M. (2021a). A Microeconomic (Vintage) Model of a Shipping Company: A Proposed Depreciation Strategy. Modern Economy, 12, 1185-1212. https://doi.org/10.4236/me.2021.128062

Goulielmos, A. M. (2021b) Scale Economics: An Economic Blessing? Should We Build Still Larger Ships? Modern Economy, 12, 1296-1319. https://doi.org/10.4236/me.2021.128068

Goulielmos, A. M. (2021c). Managing Shipping Companies, the Way Their Pioneers Did: The Case-Studies of Aristotelis S. Onassis II and Angeliki Frangou. Modern Economy, 12, 247-273. https://doi.org/10.4236/me.2021.121013

Hahn, F. H., \& Matthews, R. C. O. (1964). The Theory of Economic Growth: A Survey. Economic Journal, 74, 779-902. https://doi.org/10.2307/22228848

Harrod, R. (1948). Towards a Dynamic Economics. Macmillan.

Henderson, J. M., \& Quandt, R. (1958). Microeconomic Theory: A Mathematical Approach. McGraw-Hill Book Company.

Hicks, J. R. (1963). Theory of Wages (2nd ed.). Macmillan. https://doi.org/10.1007/978-1-349-00189-7 
Hughes, C. (1996). Ship Performance: Technical, Safety, Environmental \& Commercial Aspects (2nd ed.). LLP.

Jacques, I. (2018). Mathematics for Economics and Business (9th ed.). Pearson.

Beenstock, M., \& Vergottis, A. (1993). Econometric Modelling of World Shipping. Chapman \& Hall.

Ramsey, F. P. (1928). A Mathematical Theory of Savings. Economic Journal, 38, 543-559. https://doi.org/10.2307/2224098

Solow, R. M. (1959). Investment and Technical Progress. In K. Arrow, \& Suppes (Eds.), Mathematical Methods in the Social Sciences. Stanford.

Stopford, M. (2009). Maritime Economics (3rd ed.). Routledge. https://doi.org/10.4324/9780203891742 


\section{Appendix: Certain Policy Implications for Ports \& Fuel Oil Suppliers}

Ports and Bunker Suppliers get lion's share out of ships (!): $\$ 892,271$ out of $\$ 1,472,211$ or $61 \%$ ! So, the efforts of shipowners must be to reduce the time spent in ports and demand also a lower port cost, via INTERTANKO or INTERCARGO.

The port cost to be charged on the true carrying capacity of the ship, which is ship's net $d w t$ (less stores, bunkers and water...). These 3 items are transported free, but they increase by almost $60 \%$, going from a standard tanker of 75,000 dwt to a $225,000 \mathrm{dwt}$ !

Captains have to optimize (minimize) the factors, which antagonize ${ }^{41} \mathrm{dwt}$ : stores etc. (200 tons), water (500) and fuel (5271), which were 5971 tons totally or $2.65 \%$, on a total dwt for a $225,000-\mathrm{dwt}$ tanker! These items cost $\$ 6.72$ per $\mathrm{mt}$ or $\$ 40,125$ per almost 50 days (plus 1 Suez Canal transit)! For a 7-voyage-year the above comes to $\$ 280,875$ ! Of course, the proper amount of fuel cannot be reduced, and it had to be adequate for the ships to cross from point $A$ to point $B$ of bunker supply, plus to cope with weather conditions, and so on, but stores ${ }^{42}$ and water could be reduced. Certain ships have desalination units to economize on water. My analysis has revealed as a by-product that ports, they should provide to ships the so called "external economies" by applying newer technological progress.

\footnotetext{
${ }^{41}$ Captains may be in trouble to ascertain the true dwt of a ship, as after delivery any additional constructions may take place and a number of machines may be added on board and even fixed. This is more common in passenger ships! Whatever or whoever gets up on board reduces ship's dwt by its, his/her weight!

${ }^{42}$ This reminds me of certain of my theories inspired by the Japanese practice of "just in time". Japanese wanted to transform labor from a variable coefficient of production, into a fixed one, believing in "life employment" by conglomerate employers! Later this abandoned. To do that, they decided to minimize all kinds of stocks (spare parts in particular). This meant to maintain the minimum possible stock, say to one spare part, on the idea that a $2^{\text {nd }}$ spare part can be delivered on next day (coupled with what is known as "door to door") upon request! In shipping, when helicopter transport will become cheaper and all larger ships will obtain a pad, transport of spare parts can be done in a just in time fashion. One may think a company with 30 ships having an average budget for spare parts, stores etc. and a stock of $\$ 100,000$ p.a. for each vessel on average, kept at that level!
} 